\title{
The Critical Role of Nurr1 as a Mediator and Therapeutic Target in Alzheimer's Disease-related Pathogenesis
}

\author{
Seong Gak Jeon", , Anji Yoo,"\#, Dong Wook Chun", , Sang Bum Hong', Hyunju Chung², Jin-il \\ Kim $^{3, *}$, Minho Moon ${ }^{1, *}$ \\ ${ }^{1}$ Department of Biochemistry, College of Medicine, Konyang University, Daejeon, 35365, Republic of Korea \\ ${ }^{2}$ Department of Core Research Laboratory, Clinical Research Institute, Kyung Hee University Hospital at \\ Gangdong, Seoul 05278, Republic of Korea \\ ${ }^{3}$ Department of Nursing, College of Nursing, Jeju National University, Jeju-si 63243, Republic of Korea
}

[Received May 14, 2019; Revised June 18, 2019; Accepted July 18, 2019]

\begin{abstract}
Several studies have revealed that the transcription factor nuclear receptor related 1 (Nurr1) plays several roles not only in the regulation of gene expression related to dopamine synthesis, but also in alternative splicing, and miRNA targeting. Moreover, it regulates cognitive functions and protects against inflammationinduced neuronal death. In particular, the role of Nurr1 in the pathogenesis of Parkinson's disease (PD) has been well investigated; for example, it has been shown that it restores behavioral and histological impairments in PD models. Although many studies have evaluated the connection between Nurr1 and PD pathogenesis, the role of Nurr1 in Alzheimer's disease (AD) remain to be studied. There have been several studies describing Nurr1 protein expression in the AD brain. However, only a few studies have examined the role of Nurr1 in the context of AD. Therefore, in this review, we highlight the overall effects of Nurr1 under the neuropathologic conditions related to AD. Furthermore, we suggest the possibility of using Nurr1 as a therapeutic target for AD or other neurodegenerative disorders.
\end{abstract}

Key words: Alzheimer's disease, Nurr1, NR4A2, memory, neuroprotection, neuroinflammation

\section{The nuclear receptor related-1 protein, Nurr1}

The nuclear receptor related 1 (Nurr1) protein, also known as nuclear receptor subfamily 4 , group A, member 2 (NR4A2). Nurr 1 belongs to the nuclear receptor subfamily 4A (NR4A), which consists of NR4A1, NR4A2, and NR4A3, also known as Nur77, Nurr1, and Nor1, respectively $[1,2]$. Nurr1 is robustly expressed in the central nervous system (CNS) [3, 4]. Similar to other members of the NR4A, Nurr 1 has been considered as an orphan nuclear receptor, whose endogenous ligand has not been identified [1]. Nurr1 is well known to play an essential role in the development, function, and maintenance of midbrain dopaminergic neurons [5-7]. In particular, Nurr1 is known to play an integral role in multiple signaling pathways involved in the

*Correspondence should be addressed to: Dr. Minho Moon, College of Medicine, Konyang University, Republic of Korea. Email: hominmoon@konyang.ac.kr and Jin-il Kim, College of Nursing, Jeju National University, Republic of Korea. Email: neoreva@hanmail.net. \#These authors contributed equally to this work.

Copyright: (C) 2019 Jeon SG et al. This is an open-access article distributed under the terms of the Creative Commons Attribution License, which permits unrestricted use, distribution, and reproduction in any medium, provided the original author and source are credited. 
differentiation and phenotype of dopaminergic neurons [8]. It is also targeted by miRNAs in dopaminergic neurons, and is alternatively spliced by cyclic adenosine monophosphate (cAMP)-responsive element-binding protein (CREB)-regulated transcription co-activators [9, 10]. Notably, a recent report suggesting that CREBregulated transcription coactivator-1 (CRTC1) mediates expression of the Nurr1 gene provided evidence for specific molecular mechanisms for the regulation of Nurr1 expression in primary cortical neurons [11]. Nurr1 expression is also found to be directly induced by various stimuli such as inflammatory signals. Once Nurr1 is activated by various factors, it binds to specific DNA sequences in the promoter region of the target genes to positively regulate their expression [12].

In addition to the role of Nurr 1 in the pathogenesis of dopamine-related neurological disorders [6, 13], several studies have revealed the involvement of Nurr1 in rewardseeking behavior [14], symptoms of schizophrenia [15], and pathogenesis of Alzheimer's disease (AD) [16]. Although the endogenous ligand of Nurr1 has not yet been identified, the cognition-enhancing effects of Nurr1 agonists, which have been demonstrated in wild-type (WT) and PD mice, support the potential of Nurr1 as a therapeutic target for neurodegenerative disease [17-20].

Table 1. Overview of the possible roles of Nurr1 in AD.

\begin{tabular}{|c|c|c|}
\hline & & Referenc \\
\hline \multirow{5}{*}{ Nurr1 expression in AD } & - Nurr1 immunofluorescence intensity is reduced in the substantia nigra of AD patients & [13] \\
\hline & - Nurr1 mRNA levels are reduced in $\mathrm{APP}_{\text {swe, } \text {, nd }}$ mutant mice & {$[62,63]$} \\
\hline & $\begin{array}{l}\text { - The number of Nurr } 1(+) \text { cells is age-dependently reduced in the subiculum of } \\
\text { 5XFAD mice }\end{array}$ & [90] \\
\hline & - Nurr1 protein is co-localization with $A \beta$ at the early stage in 5XFAD mice & [90] \\
\hline & $\begin{array}{l}\text { - Nurr1 protein and mRNA are downregulated in } \mathrm{A} \beta_{1-42} \text { fibril-treated CGNs and the } \\
\text { hMSC cell line }\end{array}$ & {$[65]$} \\
\hline \multirow{6}{*}{ Neuroprotective effects } & $\begin{array}{l}\text { - MPTP-induced neurotoxic vulnerability of dopaminergic neurons is increased in } \\
\text { Nurr } 1^{(+-)} \text {mice }\end{array}$ & [59] \\
\hline & $\begin{array}{l}\text { - Nurr1 in microglia and astrocytes protects neurons by regulating the production of } \\
\text { toxic mediators }\end{array}$ & [79] \\
\hline & $\begin{array}{l}\text { - Ligand and agonist of Nurr1 shows neuroprotective effect against oxidative insult } \\
\text { such as MPTP and 6-OHAD }\end{array}$ & $\begin{array}{l}{[17,19,} \\
20]\end{array}$ \\
\hline & $\begin{array}{l}\text { - Increased expression of Nurr1 upregulates genes involved in ROS detoxification such } \\
\text { as Sesn3, Alb2, and Sod1 }\end{array}$ & [81] \\
\hline & $\begin{array}{l}\text { - In NSCs, the overexpression of Nurr1 protects against oxidative stress by } \\
\text { downregulating cell death-related proteins such as caspase- } 3 \text { and caspase-11 }\end{array}$ & {$[60]$} \\
\hline & $\begin{array}{l}\text { - Exogenous Nurr1 induces the differentiation of dopaminergic neurons, and sustained } \\
\text { Nurr1 expression improves survival of dopaminergic neurons }\end{array}$ & {$[83,149]$} \\
\hline \multirow{4}{*}{$\begin{array}{l}\text { Anti-inflammatory } \\
\text { effects }\end{array}$} & $\begin{array}{l}\text { - Nurr1 phosphorylation promotes binding to p65 and recruits the CoREST complex to } \\
\text { promoters of inflammatory genes, resulting in inhibition of neuroinflammation }\end{array}$ & [79] \\
\hline & $\begin{array}{l}\text { - Overexpression of Nurr1 suppresses inflammation, whereas knockdown of Nurr1 } \\
\text { enhances inflammation }\end{array}$ & [16] \\
\hline & $\begin{array}{l}\text { - NR4A receptors are involved in a negative feedback loop as modulators of the } \\
\text { inflammation mechanism }\end{array}$ & [93] \\
\hline & - Inflammatory stimulus (e.g., LPS) up-regulates Nurr1 mRNA expression in microglia & [96] \\
\hline \multirow{3}{*}{$\begin{array}{l}\text { Peripheral immune } \\
\text { regulation }\end{array}$} & $\begin{array}{l}\text { - Nr4a-TKO mice cannot produce } \mathrm{T}_{\mathrm{reg}} \text { cells and die early due to systemic } \\
\text { autoimmunity }\end{array}$ & [118] \\
\hline & - Nurr1 induces Foxp3 in CD4+ T cells via modulating histone modifications & [94] \\
\hline & - Nurr1 can regulate Th17 cell-mediated autoimmune inflammation & [112] \\
\hline \multirow{5}{*}{ Cell-cycle regulation } & $\begin{array}{l}\text { - Nurr1 promotes cell-cycle arrest in the G1 phase as well as differentiation of MN9D } \\
\text { cells }\end{array}$ & [134] \\
\hline & $\begin{array}{l}\text { - Overexpression of Nurr1 inhibits proliferation via increased expression of p27Kip1 } \\
\text { in VSM cells }\end{array}$ & {$[135]$} \\
\hline & $\begin{array}{l}\text { - Nurr1 overexpression restricts proliferation via upregulated expression of p18 in HS } \\
\text { cells }\end{array}$ & [136] \\
\hline & $\begin{array}{l}\text { - Nurr1 induced after ischemic injury promotes IE cell proliferation via inhibition of } \\
\text { p21 }\end{array}$ & [139] \\
\hline & $\begin{array}{l}\text { - Treatment with the Nurr1 agonist increases proliferation via phosphorylation of Akt } \\
\text { and Erk1/2 in AHP cells }\end{array}$ & {$[18]$} \\
\hline
\end{tabular}




\begin{tabular}{|c|c|c|}
\hline \multirow{5}{*}{ Neurogenic effects } & $\begin{array}{l}\text { - Nurr1 induces neural differentiation of ECP cells through an extrinsic paracrine } \\
\text { mechanism }\end{array}$ & {$[152]$} \\
\hline & - The ventral midbrain in Nurr1 knockout mice shows reduction of NPC differentiation & {$[150]$} \\
\hline & $\begin{array}{l}\text { - Nurr1 promotes dopaminergic neuron production and suppresses inflammatory } \\
\text { factors }\end{array}$ & [155] \\
\hline & $\begin{array}{l}\text { - Overexpression of Nurr1 in NPCs obtained from the SVZ of rats induces } \\
\text { dopaminergic neurons }\end{array}$ & [149] \\
\hline & $\begin{array}{l}\text { - The Nurr1 agonist amodiaquine causes a significant increase in adult hippocampal } \\
\text { neurogenesis }\end{array}$ & {$[18]$} \\
\hline \multirow{3}{*}{$\begin{array}{l}\text { Memory-enhancing } \\
\text { effects }\end{array}$} & $\begin{array}{l}\text { - Formation of long-term memory in the hippocampus depends on the } \\
\text { cAMP/PKA/CREB signaling pathway, which also controls transcription of Nurr1 }\end{array}$ & {$[48,168]$} \\
\hline & $\begin{array}{l}\text { - Inhibition of HDAC increases Nurr1 expression, and enhances memory, which is } \\
\text { attenuated by protein suppression, siRNA knockdown, and Nurr1 knockout }\end{array}$ & $\begin{array}{l}{[15,53,54} \\
171]\end{array}$ \\
\hline & $\begin{array}{l}\text { - Dominant negative Nurr1 mice inhibition of Nurr1 function impairs hippocampal } \\
\text { long-term potentiation }\end{array}$ & {$[55]$} \\
\hline \multirow{2}{*}{$\begin{array}{l}\text { Vascular pathology } \\
\text { mitigation }\end{array}$} & $\begin{array}{l}\text { - Overexpression of Nurr1 inhibits vascular lesion via reducing SMCs proliferation } \\
\text { and inflammation }\end{array}$ & {$[135]$} \\
\hline & $\begin{array}{l}\text { - Overexpression of Nurr1 reduces oxidized-low-density lipoprotein uptake and } \\
\text { inflammatory responses in macrophages }\end{array}$ & {$[178]$} \\
\hline \multirow{3}{*}{ Role in metabolism } & $\begin{array}{l}\text { - Abnormal expression of Nurr1 is associated with glucose metabolism and metabolic } \\
\text { syndrome }\end{array}$ & {$[183,184]$} \\
\hline & $\begin{array}{l}\text { - NR4A receptors are induced by metabolic-related stimuli such as fatty acids, glucose } \\
\text { and insulin }\end{array}$ & {$[185]$} \\
\hline & $\begin{array}{l}\text { - NR4A receptors including Nurr1 are involved in increased glucose uptake in the } \\
\text { skeletal muscle }\end{array}$ & {$[186]$} \\
\hline \multirow{3}{*}{$\begin{array}{l}\text { Therapeutic potential of } \\
\text { Nurr1 activation }\end{array}$} & - Nuclear receptors serve as a critical mediator of $\mathrm{A} \beta$ homeostasis & [203-205] \\
\hline & - Nurr1 expression can suppress NF- $\mathrm{KB}$ signaling pathway & [79] \\
\hline & - Nurr1 regulates AD-related pathogenesis and cognitive function in 5XFAD mice & {$[16]$} \\
\hline \multicolumn{3}{|c|}{$\begin{array}{l}\text { AD: Alzheimer's disease, A } \beta \text { : amyloid beta, APP: amyloid precursor protein, CGNs: cerebellar granule neurons, hMSC: human mesenchymal, } \\
\text { NSCs: neuronal stem cells, MN9D cells: dopamine-synthesizing cell line, VSM cells: vascular smooth muscle cells, HS cells: hematopoietic stem } \\
\text { cells, IE cells: intestinal epithelial cells, AHP cells: adult hippocampal neural precursor cells, CoREST: co-repress or for RE1 silencing transcription } \\
\text { factor, NPCs: neural precursor cells, SVZ: subventricular zone, SMCs: Smooth muscle cells, ECP cells: embryonic cortical prec ursor cells, HDAC } \\
\text { histone deacetylase, BACE1: beta-secretase } 1\end{array}$} \\
\hline
\end{tabular}

\section{The roles of Nurr1 in AD-related pathology}

$\mathrm{AD}$ is known to be the most common cause of dementia and is responsible for $60 \%-70 \%$ of the cases of dementia $[21,22]$. AD patients exhibit impairment of cognitive functions, which is mediated by abnormal accumulation of amyloid plaques containing amyloid beta $(A \beta)$ and neurofibrillary tangles (NFT) in the brain [23-25]. With the increasing focus on $\mathrm{AD}$ over the past century because of the gradual aging of the global population, the pathophysiologies of AD [26-29], as well as its clinical manifestations [30, 31], diagnosis [32, 33], and genetic characteristics [34, 35] are now relatively well understood. Several studies on therapeutic approaches for $\mathrm{AD}$ have been performed, including those involving cholinesterase inhibitors, $N$-methyl-D-aspartate (NMDA) receptor antagonists [36-39], and anti-A $\beta$ therapy [4043]. Nevertheless, there is no disease-modifying therapy yet [44]. Although the exact mechanisms of $\mathrm{AD}$ pathogenesis are unclear, intracellular and extracellular $\mathrm{A} \beta$ are thought to be major causative factors associated with $\mathrm{AD}$-related pathologies, such as neurodegeneration and cognitive dysfunction [45-47]. Interestingly, Nurr1 is known to act as a critical regulator of hippocampal function, hippocampal synaptic plasticity, and cognitive functions [15, 48-55], and is an essential mediator of neuroprotection or anti-inflammation after exposure to neuropathological stress [19, 56-61]. In addition, a number of studies have indicated altered levels of Nurr1 in $\mathrm{A} \beta$-treated neuronal cells, animal models of $\mathrm{AD}$, and the brains of patients with $\mathrm{AD}$ [13, 62-65], implying that Nurr1 may play a role in the pathogenesis of AD. Recent studies have shown that $A \beta_{1-42}$ fibrils not only lead to upregulation of tau hyperphosphorylation and presenilin 1 mRNA, which are hallmarks of AD pathology, but also significantly reduce Nurr1 mRNA levels in an in vitro model of AD [65]. Immunofluorescence staining with Nurr1-specific antibody in 5XFAD mice, an animal model of $A D$, showed that the Nurr1 protein is markedly expressed in the brain areas with $A \beta$ accumulation. Moreover, the number of Nurr1-expressing cells is decreased in 5XFAD mice with AD progression, compared with WT mice [64]. In contrast, the levels of miR-184, which directly targets the 3' UTR of the NR4A2 
transcript, are reduced in the hippocampus of late-onset $\mathrm{AD}$ patients. In addition, expression of $N R 4 A 2$ and miR184 is inversely correlated [66]. These findings suggest that Nurr1 is not only highly implicated in cases of AD, but also can modulate $\mathrm{AD}$ pathogenesis. The following sections will discuss the critical roles and effects of Nurr 1 in neurodegenerative diseases (Table 1).

\subsection{Neuroprotective effects of Nurr1}

Neuronal death is the main pathogenic factor underlying neurodegenerative diseases such as AD and PD [67, 68]. Under neuropathological conditions, including neuroinflammation, excitotoxicity, and oxidative stress, neurons can be rescued by upregulation or activation of neuroprotective factors such as reactive oxygen species (ROS) scavengers or anti-apoptotic molecules [69-71]. Therefore, induction of neuroprotective factors may be a therapeutic strategy for the treatment of neurodegeneration-related diseases.

Several studies have shown that Nurr1 has antiapoptotic or neuroprotective roles against neuropathological stress or insults [56-60, 72-74]. Nurr1 expression is known to be regulated by various stimuli such as inflammatory cytokines, cAMP, and growth factors [75-77]. In comparison with WT mice, neurons from Nurr1 heterozygous mice exhibit greater vulnerability to neurotoxic challenges [59]. In addition, survival of dopaminergic neurons in the midbrain of mice was inhibited by genetic deletion of Nurr1 during development [78]. Moreover, it has been demonstrated that Nurr1 inhibits dopaminergic neuronal loss by suppressing inflammatory stimuli in the microglia and astrocytes [79]. Nurr 1 changes its subcellular distribution in response to oxidative stress [80]. In addition, the ligand and agonist of Nurr1 showed neuroprotective effects on subsequent oxidative insult such as MPTP and 6-OHAD $[17,19,20]$. Especially, increased expression of Nurr1 by lentiviruses upregulated genes involved in ROS removal, such as Sesn3, Abl2, and Sodl, and demonstrated that Nurr1 is an essential mediator of CREB-dependent neuroprotection in oxidative stress [81]. Furthermore, Nurr1 overexpression protected neuronal stem cells against oxidative stress through downregulating cell death related protein such as caspase-3 and caspase-11 [60]. A number of studies have demonstrated the protective role and correlation of Nurr1 in cell death by oxidative stress, but the detailed molecular mechanism of Nurr1 against oxidative stress remains unclear $[17,19,20,60$, 81-83]. Interestingly, a contemporary study reporting the direct binding of dopamine metabolite on Nurr1 and its stimulation of Nurr1 activity may provide an evidence for mechanism underlying the role of Nurr1 in sensing and responding the oxidative stress [84]. Moreover, Jo et al. reported that exogenous Nurr1 expression in neural precursor cells (NPCs) induced differentiation of dopaminergic neurons, higher resistance to toxic stimuli, and enhanced survival [83]. Although there has been only a few reports regarding the direct roles of Nurr1 in neuronal death in $\mathrm{AD}$, interestingly, it has been demonstrated that Nurr1 is not only involved in the protection of dopaminergic neurons but also of GABApositive neurons in vitro [79]. Since the levels of GABAergic neurotransmission as well as GABAergic signaling are significantly altered in $\mathrm{AD}[85,86]$, it can be speculated that strategies for preserving GABAergic neurons by maintaining Nurr1 expression. All these reports suggest that Nurr1 may have neuroprotective effects against the pathogenesis of neurodegenerative diseases. A recent study has reported the protective role of Nurr1 in neuronal death in AD [16].

\subsection{Anti-inflammatory effects of Nurr1}

Neuroinflammation is one of the most important aspects of $\mathrm{AD}$ pathogenesis. Although resting glial cells maintain the microenvironment in the brain, activated glia contributes to neuronal damage by releasing neurotoxic molecules [87, 88]. Over-activated microglia and astrocytes release several detrimental compounds such as ROS, superoxide $\left(\mathrm{O}_{2}{ }^{--}\right)$, nitric oxide $(\cdot \mathrm{NO})$, and cytokines, which cause neuronal damage. The $\mathrm{A} \beta$ peptide is known to directly activate microglial cells, and activated cells are recruited around $\mathrm{A} \beta$ plaques before symptom development [89]. In addition, our previous studies revealed that $A \beta$ oligomers $(A \beta O)$ may induce both gliosis and neurodegeneration in the animal brain [90-92]. A significant increase in the number of microglial cells and decrease in the number of neurons were simultaneously observed in the brain of $\mathrm{A} \beta \mathrm{O}$-injected mice [90-92]. NR4A receptors are promptly activated by inflammatory stimuli, thus regulating not only initiation of inflammatory responses but also in the late stages of inflammation. NR4A receptors are involved in a negative feedback loop as modulators of inflammation [93]. Nurr1 can mediate inflammatory responses and regulate the function of immune cells [94, 95]. In microglia, inflammatory stimuli such as lipopolysaccharides (LPS) up-regulate Nurr1 mRNA expression [96]. Notably, Nurr 1 shows potent anti-inflammatory activity in the CNS. In microglia and astrocytes, Nurr 1 receptors inhibit the expression of pro-inflammatory cytokines, which are neurotoxic and eventually induce neuronal death, whereas reduction of Nurr1 enhances the inflammatory responses [79]. Nurr 1 mediates the GSK3 $\beta$-dependent repression of nuclear factor kappa-light-chain-enhancer of activated $\mathrm{B}$ cells (NF- $\kappa \mathrm{B})$. Mechanistically, inflammatory signals induce Nurr1 phosphorylation and sumoylation, thus 
promoting Nurr1 binding to p65 and recruitment of the co-repressor for the RE1 silencing transcription factor (CoREST) complex to promoters of inflammatory genes, resulting in modulation of neuroinflammation [79]. Interestingly, a previous study revealed that deletion of amino acids 1-31 from the N-terminal region of Nurr1 yields better performance in transcription compared to full-length Nurr1 [97]. In addition, a recent study has provided direct evidence that modulation of Nurr1 can be involved in $A \beta$-mediated neuroinflammation [16]. In conclusion, Nurr1 can serve as a possible therapeutic target for treatment of $\mathrm{AD}$ by inhibiting the transcription of inflammatory genes and modulating the function of immune cells.

\subsection{Peripheral immune cell modulation of Nurr1}

The early stage of AD involves both the activation of microglia and astrocytes overexpressing cytokines around the $A \beta$ plaques and an increase in the levels of proinflammatory cytokines in the peripheral blood [98]. In addition, the cross-talk between the peripheral blood and the brain via a damaged blood-brain barrier (BBB) may be enhanced in $\mathrm{AD}$ patients, thereby contributing to neuroinflammation in AD [99]. As evidenced, an increase in the number of $\mathrm{T}$ cells was observed in the brain parenchyma of AD patients [100]. Several lines of evidence have indicated that modulation of $\mathrm{T}$ helper $(\mathrm{Th})$ cells may be involved in AD pathologies [101-104]. In particular, CD4 and CD8 T cells specifically migrated to the $\mathrm{A} \beta$ plaques, thus enhancing elimination of $\mathrm{A} \beta$ plaques [105]. Moreover, immunization with the $\mathrm{A} \beta_{42}$ DNA trimmer was shown to suppress antigen-specific Th17 and Th1 cell proliferation [106].

Peripheral blood mononuclear cells, CD4+ T cells and monocytes obtained from patients with multiple sclerosis (MS) have been reported to have decreased Nurr1 gene expression [107, 108]. In addition, microarray analysis showed that key nuclear receptor family genes such as NR4A1 (Nur77) and NR4A2 (Nurr1), which are important for the nuclear receptor-dependent apoptosis in the peripheral blood of the pre-disease state in MS patients, were suppressed [109]. In contrast, overexpression of Nurr1 was observed in peripheral blood T cells derived from relapsing-remitting MS patients [110]. In an experimental autoimmune encephalomyelitis (EAE) model that serves as an animal model of MS, effector T cells infiltrated the parenchyma of the CNS [111]. Nurr1 is selectively over-expressed in $\mathrm{T}$ cells in the peripheral blood whereas expression of Nurr1 in the T cells in lymphoid organs did change during the induction of EAE. In addition, interleukin (IL)-17-producing tyrosine hydroxylase (TH)-positive cells express Nurr1 regardless of interferon (IFN)- $\gamma$ secretion [112]. Hence, since Nurr 1 could be a useful biomarker for determining the status of $\mathrm{T}$ cells in MS [113], assessment of Nurr1 expression in T cells in AD could also be useful to identify changes in $\mathrm{T}$ cell activation status. In addition, heterozygous Nurr1 mice promoted early onset of EAE and increased the infiltration of inflammatory cells into the spinal cord [114], indicating that Nurr1 is involved in the pathophysiology of autoimmune diseases such MS. Consequently, Nurr1 could be an innovative therapeutic target for various autoimmune diseases. In human inflammatory joint disease, Nurr 1 has been identified as a molecular target of methotrexate (MTX)-related reactions. MTX considerably subdues Nurr1 expression in patients with active psoriatic arthritis. In the synovial tissue, MTX selectively regulates Nurr1 induced by inflammatory stimulation and also modulates expression of growth factors in resident cells. Moreover, suppressive effect of MTX on Nurr1 expression is mediated by adenosine release [115].

Because Nr4a receptors play an important role in initiating regulatory $T\left(T_{\text {reg }}\right)$ cell development in the thymus [94, 116, 117], the role of $\mathrm{Nr} 4$ a receptors in peripheral immune regulation has been examined in $\mathrm{Nr} 4 \mathrm{a}-$ triple-knockout (Nr4a-TKO) mice, Nur77 $\left(\mathrm{Nr}_{\mathrm{al}}\right)^{-/-}$, Nurr1 $(N r 4 a 2)^{-/-}$, and Nor-1 $(N r 4 a 3)^{-1-}$. The Nr4a-TKO mice could not produce $\mathrm{T}_{\text {reg }}$ cells and died early due to systemic autoimmunity [118]. Specifically, Nurr1 binds directly to the Foxp3 promoter, leading to activation of transcription and the development of $\mathrm{T}_{\mathrm{reg}}$ cells. In addition, Nurr 1 has been reported to bind directly to the regulatory regions of Foxp3, at which Nurr1 intervenes via histone modifications. Furthermore, in Nurr1deficient $\mathrm{T}$ cells, aberrant Th1 induction is increased but $\mathrm{T}_{\text {reg }}$ cell induction is rather decreased [94]. In conclusion, Nurr1 plays central roles not only in regulating the induction and suppressive functions of $\mathrm{T}_{\text {reg }}$ cells but also in inhibiting aberrant Th1 induction. Moreover, Nurr 1 can regulate the Th17 cell-mediated autoimmune inflammation, contributing to the pathogenesis of MS, an immune disease of the nervous system [112]. Since peripheral immune functions are involved in the pathogenesis of $\mathrm{AD}[119,120]$, modulation of peripheral immune responses though Nurr1 may be a potential therapeutic strategy against $\mathrm{AD}$.

\subsection{Cell-cycle regulation of Nurr1 and AD}

Neurons are generally considered as postmitotic cells, and can cell undergo cell cycle re-entry in neurodegenerative conditions [121, 122]. Basal forebrain and hippocampal pyramid neurons in the brain with $\mathrm{AD}$ have been reported to progress from the G1-phase to the S-phase [123]. In brains with $\mathrm{AD}$ and mild cognitive impairment, the expression levels of markers associated with cell cycle 
and proliferation, such as the proliferating cell nuclear antigen (PCNA), cyclin $\mathrm{D}$, and $\mathrm{B} 1$, are increased in various regions including the entorhinal cortex, hippocampus, and nucleus basalis of Meynert [124]. Moreover, the presence of active cdc2 and cyclin $\mathrm{B}_{1}$ complex was observed in the AD brain tissue [121]. In addition, senescence-accelerated mice-prone 8 , which show the major pathologic features of $\mathrm{AD}$ such as $\mathrm{A} \beta$ accumulation and tau phosphorylation, not only show enhanced CDK5 and GSK3 $\beta$ expression, but also show increased expression of various cell-cycle re-entry markers such as CDK2, cyclins A, D1, E, and B [125]. There are several reports on the correlation between cellcycle-related kinases and histological hallmarks of AD. $\mathrm{p} 25$, a truncated form of the subunit p35 that activates CDK5, is not readily degraded and is found to accumulate in the brain of patients with AD. Subsequently, the formation of the p25/CDK5 complex induced tau hyperphosphorylation and apoptosis [126]. In addition, soluble $A \beta$ oligomers also promoted neuronal cell-cycle re-entry via phosphorylation of tau [127]; cell-cycle progression through CDK5 and $\mathrm{CDC} 2$ kinases induced phosphorylation of the amyloid precursor protein (APP) [128-130], and phosphorylation of APP facilitated A $\beta$ generation [131]. Moreover, a broad promotion of the cell cycle in the AD brain leads to a mitotic catastrophe, which is the result of dysregulated or failed mitosis, suggesting that this may be one of the mechanisms of neuronal death in $\mathrm{AD}[132,133]$.

The role of Nurr 1 in the cell cycle has been suggested after assessment of cell-cycle-related molecules in various cells. In the dopamine-synthesizing cell line (MN9D cells), Nurr1 promoted cell-cycle arrest in the G1 phase as well as morphological differentiation, and these effects did not require the formation of heterodimers with retinoid X receptors (RXR) [134]. In vascular smooth muscle cells, lentivirus-mediated Nurr1 overexpression inhibited proliferation with increased expression of the crucial cell-cycle inhibitor $\mathrm{p} 27^{\mathrm{Kip} 1}$ which induces G1 cellcycle arrest [135]. Similarly, in hematopoietic stem cells, Nurr1 overexpression restricted cell proliferation by upregulating the expression of p18, which inhibits the cyclin D/CDK4/6 complexes required for cell-cycle progression in G1-phase [136]. In addition, the mechanism by which Nurr1 promotes migration and inhibits proliferation in mesenchymal stem cells (MSCs) may involve the ability of Nurr1 to reduce the percentage of cells in the S-phase [137]. Furthermore, overexpression of Nurr1 in olfactory bulb stem cells induces cell-cycle exit, inhibits proliferation, and induces a TH neuronal fate mediated by Fgfr2 expression [138]. In contrast, Nurr1 induced after intestinal ischemia/reperfusion injury promoted proliferation of intestinal epithelial cells via inhibition of $\mathrm{p} 21^{\mathrm{Waf} 1 / \mathrm{cIP} 1}$ gene transcription [139].
Moreover, in the mouse hippocampus and adult hippocampal neural precursor cells, pharmacological stimulation of Nurr1 with a Nurr1 agonist resulted in increased proliferation as well as phosphorylation of Akt and Erk1/2 [18].

These results suggest that Nurr1 may interfere negatively or positively with the cell cycle depending on the cell type and its environment. They also suggest that Nurr1 may have a positive effect on AD by promoting proliferation of neural stem cells or by suppressing the abnormally promoted cell cycle in the AD brain. However, the correlation of Nurr1 with the cell cycle in $\mathrm{AD}$ has not yet been directly reported.

\subsection{Neurogenic effects of Nurrl in the adult brain}

Neurons are generated and differentiated from neural stem cells in the adult brain. This process is called adult neurogenesis, and takes place mainly in two brain regions, the subgranular zone of the hippocampal dentate gyrus (SGZ) and the subventricular zone of the lateral ventricle (SVZ) [140, 141]. In particular, adult hippocampal neurogenesis at SGZ regulates learning and memory functions by generating newborn neurons derived from neural stem cells [140,142, 143]. Studies have shown that altered hippocampal neurogenesis occurs in the early stage of $\mathrm{AD}$ even prior to pathologic changes [144]. Several key molecular players involved in $A D$ pathogenesis have been found to regulate hippocampal neurogenesis [144-148].

A recent study demonstrated that treatment with the Nurr1 agonist amodiaquine (AQ) in mice significantly contributed to enhanced adult hippocampal neurogenesis, resulting in enhancement of cognitive function. Moreover, knockdown of Nurr1 inhibited proliferation of adult hippocampal neural stem cells [18]. In addition, overexpression of Nurr1 in NPCs isolated from the SVZ of adult rats resulted in functional dopaminergic neurons. Transplantation of Nurr1-induced dopaminergic neurons lead to differentiation and integration in vivo, and improved the behavioral disorders of parkinsonian rats [149]. Furthermore, in vivo studies showed that Nurr1deficient mice exhibited deficits in the differentiation of dopaminergic neurons in the ventral midbrain $[78,150]$. In support of this notion, Nurr1 is not only well known to play a key role in the differentiation and maturation of dopaminergic neurons [151-155] but may also exert an important role in neurogenesis [156]. These studies suggest that Nurr1 may contribute to the rescue of impaired adult neurogenesis in AD. Indeed, a recent study has shown that administration of the Nurr1 agonist AQ can reverse impaired neuronal fate specification of hippocampal neural stem cells in $A \beta$-overexpressing mice [16]. 


\subsection{Memory-enhancing effects of Nurr1}

$\mathrm{A} \beta$ is known to be a major contributor of memory impairment in $\mathrm{AD}$, and results in cognitive deficits by inducing neuroinflammation, neuronal death, inhibition of synaptic transmission, synaptic loss, and impairment of adult neurogenesis [88, 157-159]. Furthermore, under AD conditions, there are other pathways that cause cognitive dysfunction and memory decline, such as abnormal activity of the NMDA receptor [160, 161]. Recent studies have suggested that Nurr1 may play a role in the regulation of cognitive function, since hippocampusdependent memories were impaired in Nurr1 knockdown or NR4A dominant-negative transgenic mice [48, 49, 54] and an increase in Nurr1 mRNA expression was observed when mice were submitted to spatial learning tasks [50]. Thus, it is important to investigate whether Nurr1 has a direct influence on AD-related cognitive functions.

Several studies have discovered that Nurr1 regulates learning and memory functions [15, 49-55]. In many systems, the CREB signaling pathway is important for transcription of memory-related genes [162], and this pathway controls transcription of Nurr1 [163]. Additionally, long-term memory in the hippocampus depends on CREB-related pathways that can regulate Nurr1 expression [48, 164-168]. Several studies demonstrated that behavioral task training increases Nurr1 gene expression in subregions of the hippocampus $[50,53,54]$. Moreover, a network analysis of genes in the dentate gyri of long-term potentiation-induced rats revealed that expression of NR4A nuclear receptors, including Nurr1, was upregulated [169]. Expression of Nurr1 in cultured hippocampal neurons is revealed to be increased after treatment with GABA antagonists [170].

Inhibition of histone deacetylase (HDAC) by trichostatin A increases Nurr 1 expression, and enhances memory [171]. Similarly, enhancement of memory by HDAC inhibition is attenuated and memory enhancement is impaired by negative protein expression of $\mathrm{Nr} 4 \mathrm{a}$ family receptors [54]. Moreover, memory functions are impaired by siRNA knockdown of Nr4a2 [53] and generation of heterozygosity for the Nurr1 gene [15]. A recent study also revealed the importance of the NR4A family, including Nurr1, showing that hippocampal long-term potentiation was impaired in dominant-negative $\mathrm{Nr} 4 \mathrm{a}$ transgenic mice [55]. Interestingly, although the precise mechanism for cognitive enhancement is unclear, one placebo-controlled study showed that the intermittent preventive administration of $\mathrm{AQ}$, an antimalarial agent and Nurr1 agonist, enhanced cognitive performance in semi-immune schoolchildren [172]. Furthermore, a recent study has demonstrated that administration of the Nurr1 agonist AQ restored damaged spatial working memory in $A \beta$-overexpressing mice [16]. However, how Nurr1 affects $\mathrm{AD}$ patients with memory failure has not been examined, and we anticipate that further studies on Nurr1 will uncover its importance on cognitive functions in brains with $\mathrm{AD}$.

\subsection{The role of Nurr1 in vascular pathologies}

Cerebral amyloid angiopathy (CAA) is an AD-related histopathology showing pathological changes such as deposits of $A \beta$ in the blood vessels of the CNS and the walls of leptomeningeal arteries [173]. CAA is not only associated with the $A \beta$ burden of the brain parenchyma, but also occasionally induces necrosis resulting in cerebral hemorrhage $[174,175]$. However, the degree of CAA varies between $\mathrm{AD}$ brains, and the majority of $\mathrm{AD}$ patients showing microvascular amyloid deposits do not experience cerebral hemorrhage [176]. Nonetheless, because CAA could contribute to cortical dysfunction, regulation of vascular $A \beta$ accumulation is suggested for mitigation of secondary AD pathology.

In human atherosclerosis, expression of NR4A including Nurr1 receptors is increased in macrophages after inflammatory stimulation [177]. In addition, overexpression of Nurr1 inhibited vascular lesion formation through reduction of smooth muscle cell proliferation and inflammatory response [135, 178]. These findings prove that endogenous Nurr1 suppresses macrophage activation, foam-cell formation, and further differentiation. Thus, it provides further evidence that atherogenesis could be prevented by modulation of Nurr 1 expression. Therefore, Nurr1 may be proposed as a novel therapeutic target for preventing vascular disruptionrelated diseases mediated by $\mathrm{AD}$.

\subsection{The role of Nurr1 in metabolism}

There are a number of studies describing both a correlation between type 2 diabetes and the risk of $\mathrm{AD}$, and an association of hyperglycemia with $\mathrm{AD}$ pathophysiology $[179,180]$. In addition, it has been reported that excess weight in middle age is related to increased risk of AD [181]. Metabolic hormones such as insulin, leptin, ghrelin, and adiponectin have been reported to have therapeutic potential and are also involved in the pathogenesis of AD [182]. Since AD could be accompanied by metabolic disturbances, normalization of metabolism will provide new insights into $\mathrm{AD}$ treatment.

There are several studies showing the roles of $\mathrm{Nr} 4 \mathrm{a}$ receptors associated with metabolic functions. In particular, it has been reported that aberrant expression of Nurr1 is correlated to glucose metabolism and metabolic syndrome [183, 184]. Moreover, Nr4a receptors are 
expressed under metabolism-related stimuli including cold, fatty acids, glucose, insulin, and cholesterol. Therefore, it has been suggested that $\mathrm{Nr} 4 \mathrm{a}$ receptors can be therapeutic targets for metabolism-related disorders [185]. There is also compelling evidence suggesting that $\mathrm{Nr} 4 \mathrm{a}$ receptors show a potent association with the course of type 2 diabetes through regulation of insulin sensitivity and glucose homeostasis. Even though the mechanisms underlying the regulation of glucose metabolism by $\mathrm{Nr} 4 \mathrm{a}$ receptors have not been elucidated, $\mathrm{Nr} 4 \mathrm{a}$ receptors are identified as potential biological targets for diabetic patients [186]. However, the association of Nurr1 with carbohydrate metabolism is currently unclear. Therefore, identification of the correlation between Nurr1 and metabolic disorders in $\mathrm{AD}$ will be a novel pioneering field of study.

\subsection{The role of Nurr1 in the habenula}

The habenula is a part of the epithalamus in the diencephalon, located dorsal-medial to the posterior thalamus. It is divided into two regions: (1) the lateral habenula $(\mathrm{LHb})$, which is innervated by the rostromedial tegmental nucleus (RMTg) to the dopamine-related regions, such as the ventral tegmental area (VTA) and substantia nigra (SN) or the serotonin system, such as the dorsal raphe nucleus and median raphe nucleus, and (2) the medial habenula $(\mathrm{MHb})$, which is innervated with the serotonin system through the interpeduncular nucleus (IPN) [187-190]. The habenula, which is connected to the limbic system, basal ganglia, and pineal gland, is involved in the reward system and cognitive functions such as learning, memory, and attention [191]. Therefore, it has been suggested that the habenula may be involved in psychiatric disorders such as depression, schizophrenia, and drug-induced psychosis [192].

In adults and during development, the Nurr1 and $\mathrm{Nr} 4 \mathrm{a} 2$ genes are robustly and specifically expressed in the $\mathrm{MHb}$ expressing both the choline acetyltransferase in the ventral part and the neuropeptide SP in the dorsal part [191, 193-195]. In addition, Nurr1 has been reported to mediate a gene pathway involved in habenula development regulated by the POU-domain transcription factor Brn3a [195]. Notably, several studies have suggested that habenular activity is involved in depression, which is one of the most common psychiatric symptoms in $\mathrm{AD}$ and a risk factor for $A D$ development.

In the genetic helpless model and $\alpha$-methyl-paratyrosine-induced depression model, brain metabolism and glucose metabolism were elevated in the habenular compared to the control while metabolism of other brain regions was reduced [196, 197]. In patients with depression, it is shown that habenula activity is strongly correlated with dorsal raphé nuclei activity providing an evidence for the important roles of feedback pathway between habenula and dorsal raphé nuclei in controlling release of serotonin [198]. Application of deep brain stimulation to the LHb in a therapy-refractory patient with depression caused successful remission of depression, clarifying the relationship between the habenula and depression [199]. These reports suggest that upregulation of Nurr1 may have a positive effect on not only ADrelated pathology but also the psychiatric symptoms that may occur in patients with $\mathrm{AD}$.

\section{Therapeutic potential of Nurr1 activation for AD treatment}

As described so far, Nurr1 has the potential to mitigate the various pathophysiological consequences caused by $\mathrm{AD}$. Nurr1 inhibits NF- $\mathrm{B}$ signaling by binding to and clearance of NF- $\kappa B-p 65$ [79]. Therefore, it can be speculated that modulation of Nurr1 expression can suppress neuroinflammatory responses as well as betasecretase 1 (BACE1), which is mediated by $\mathrm{NF}-\kappa \mathrm{B}$ signaling [200]. In addition, Nurr1 plays a neuroprotective role against neuronal death induced by various toxic mediators such as ROS and 1-methyl-4phenyl-1,2,3,6-tetrahydropyridine (MPTP) [59, 60]. Furthermore, upregulation of Nurr1 has been reported to enhance cognitive function as well as increase hippocampal neurogenesis by enhancing the proliferation and differentiation of NPCs [18]. Considering the beneficial effects of Nurr1 enhancement on the pathological symptoms associated with $\mathrm{AD}$, such as neuroinflammation, neuronal loss, impaired neurogenesis, and cognitive dysfunction, compensation and enhancement of the degenerated Nurr 1 in AD patients may be a promising therapeutic target. Remarkably, one recent study reported that Nurr1 regulates $A D$-related pathogenesis and cognitive function in $A \beta$ overexpressing mice, supporting the therapeutic potential of Nurr1 for AD [16].

Interestingly, Nurr1 not only forms homo- or heterodimers with other members of the NR4A family, but can also forms heterodimers with RXRs via DR5 response element [201]. In addition, since the activation of nuclear receptors such as RXR, liver X receptor (LXR), and peroxisome proliferator-activated receptor (PPAR) $-\gamma$ is known to affect $A \beta$ generation and $A \beta$ clearance, Nurr 1 may contribute to the alleviation of $A \beta$-related pathophysiology through interactions with other nuclear receptors [202-205].

Therefore, many researchers have applied various methods to identify potential activators, ligands, and agonists of Nurr1 and have suggested several candidate structures [206-208]. To date, several Nurr1 agonists/activators have been identified and have shown 
positive effects in autoimmune disease and various PD models, suggesting the potential for the therapeutic effect of Nurr1 in neurodegenerative disease including AD [19, 20,209-213]. Therefore, a breakthrough for AD treatment will be to prove the efficacy of Nurr1 agonists/mimetics or gene delivery of Nurr1 in animal experiments or clinical trials. A number of studies have suggested that modulation of Nurr1 function may serve as a great strategy to control $\mathrm{AD}$ pathogenesis (Fig. 1), and one recent study has shown a colocalization and correlation between Nurr1 and $A \beta$, and demonstrated that administration of Nurr1 agonists alleviates AD-related pathologies in $\mathrm{A} \beta$-overexpressing mice [16].

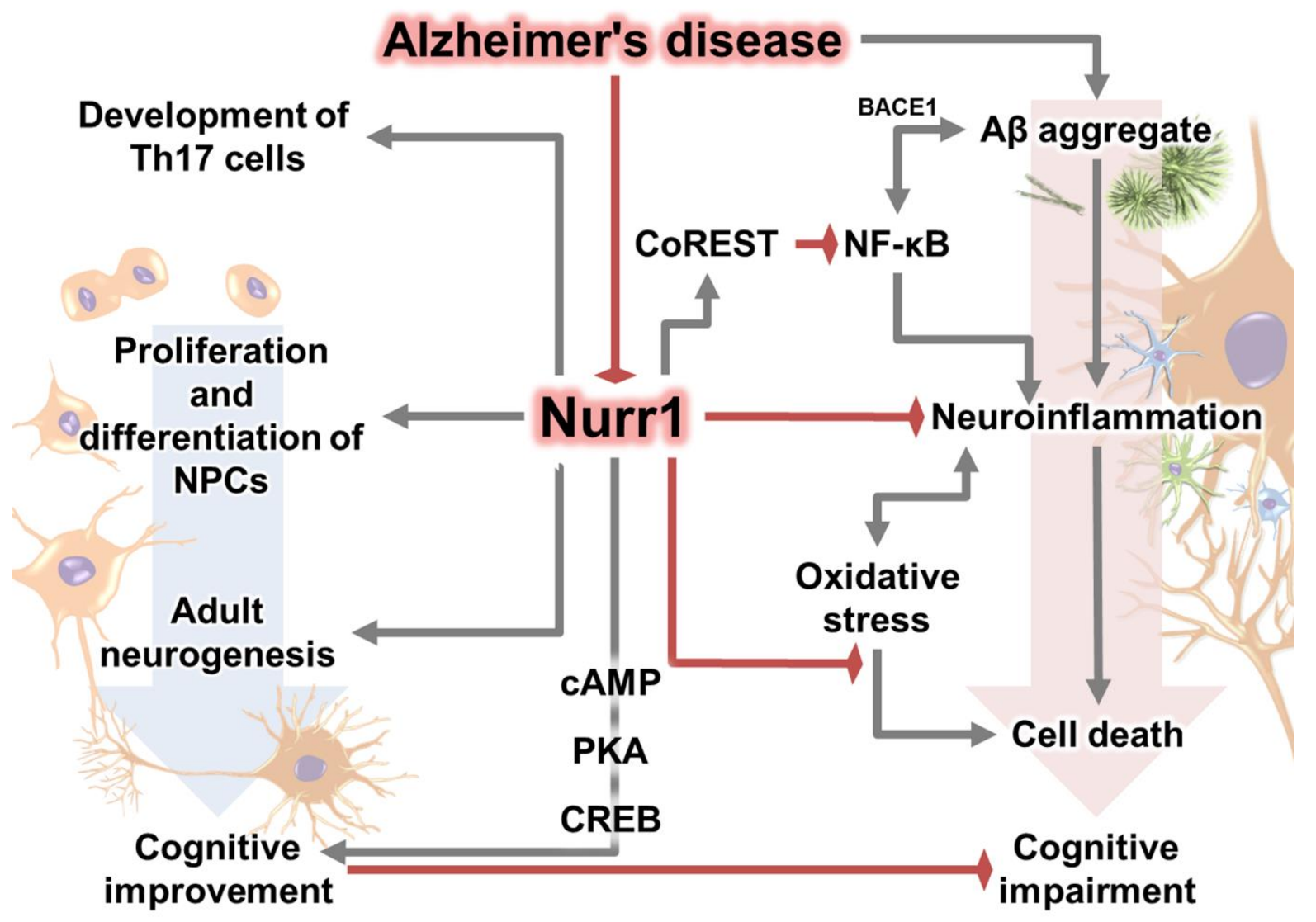

Figure 1. Overview of effect of Nurr1 in Alzheimer's disease.

\section{Nurr1 and brain disorders}

As mentioned earlier, Nurr1 can contribute to the beneficial effects on $\mathrm{AD}$-associated pathologies and may have therapeutic potential for AD. Notably, there have been studies regarding the roles of Nurr1 in various conditions in related to AD pathologies. It is speculated that reviewing the roles of Nurr 1 in these conditions could provide and extend insights about possible applications of Nurr1 in the modulation of AD pathogenesis. In the following sections, the roles of Nurr1 in brain disorders will be described.

\subsection{Parkinson's disease}

Nurr1 is known to be a key regulator of the development and maintenance of dopaminergic neurons in the midbrain $[7,78,214,215]$ and plays an important role in inhibiting neuronal death through suppression of inflammatory gene expression in microglia and astrocytes [79, 216]. Therefore, numerous studies have investigated whether Nurr1 may be associated with the pathogenesis of PD, which results from the degeneration of midbrain dopaminergic neurons [217]. In addition to decreased expression of Nurr1 in postmortem brain tissue and the peripheral blood of PD patients, a functional mutation of Nurr1 was found in PD [13, 218-220]. Interestingly, activation of Nurr1 or the Nurr1:RXR $\alpha$ heterodimer by 
agonists such as AQ, SA00025, and BRF110 has been reported to diminish neuronal loss, neuroinflammation, and behavioral symptoms that occur in 6hydroxydopamine or MPTP-induced PD models [19, 20, 221, 222]. Remarkably, it has been reported that Nurr1 expression is down-regulated in dopaminergic neurons with NFTs of the SN of AD patients. This results indicate that dysregulation of Nurr1 is associated with tauopathies in the dopaminergic neurons of $\mathrm{AD}$ patients [13]. In contrast, a recent study demonstrated that Nurr1 expression is not altered in the $\mathrm{SN}$ of postmortem brains of $\mathrm{AD}$ patients [16]. This inconsistency may be due to the presence of NFT in the neurons of AD brains. As Nurr1 expression levels were not altered in neurons without NFT [13], although the latter study did not provide further information regarding the presence of NFT in the neurons [16]. These data provide evidence that Nurr1 may be a relevant target for alleviating $\mathrm{AD}$ pathogenesis, especially in tauopathy.

\subsection{Ischemic stroke}

A recent study has shown that Nurr1 expression was dynamic following acute ischemia induced by middle cerebral artery occlusion (MCAO)/reperfusion in a rat model. There was a negative correlation between Nurr1 and infarct volume up to 12 hours after ligation, but a positive correlation was observed after 24 hours. Nurr 1 overexpression inhibited tumor necrosis factor $-\alpha$ (TNF- $\alpha$ ) levels in microglia. Increase of Nurr 1 expression through suppression of miR-145-5p, a negative regulator of Nurr1 alleviated infarct volume and improved the neurological outcomes in an acute stroke model [223]. In addition, transplantation of Nurr1-overexpressing human embryonal carcinoma cells into the ischemic striatum restored the behavioral disorder in a transient MCAO rat model [153]. Considering that TNF- $\alpha$ released from $A \beta-$ activated microglia is a key cytokine causing cell cycle events, which are related to pathogenesis of neuronal death in AD [224], these regulatory effects of Nurr1 on microglial activation could be a therapeutic target for $\mathrm{AD}$ as well as ischemic stroke.

\subsection{Schizophrenia}

Nurr1 heterozygous mice exhibited behavioral patterns associated with the symptoms of schizophrenia and were suggested as a potential animal model of schizophrenia $[15,51]$. Furthermore, protein and mRNA expression levels of Nurr1 were reduced in the prefrontal cortex of schizophrenia patients [225]. Considering that the abnormal function of dopaminergic neurons in the cerebral cortex and subcortical areas is associated with schizophrenia [226], the changes in Nurr1 expression in schizophrenia address necessitate studies examining the correlation between schizophrenia and Nurr1. Despite that hyperactivation of dopaminergic neurotransmission, conventionally considered a major hypothesis for pathology schizophrenia, these findings may support the recent challenges against the conventional dopamine hypothesis [226]. In relation to changes in Nurr1 expression in $\mathrm{AD}$, the reduced number of Nurr1expressing cells in subiculum of AD model mice with disease progress [64] and decreased levels of dopamine in various regions including the hippocampus of Nurr1 heterozygous mice, a schizophrenic animal model [15], may demonstrate some similarities in molecular changes involving both disorders as well as provide additional insights for further studies comparing mechanisms between two diseases.

\subsection{Addictive behaviors}

Although the role of Nurr1 in addiction is controversial, depending on the duration of treatment and the drug used, a number of studies have reported that the administration of addictive drugs such as cocaine and heroin reduces Nurr1 transcript levels in the midbrain [227-230]. In addition, Nurr1 heterozygous mice exhibited reduced reward-seeking behaviors mediated by dopaminergic neurotransmission and were vulnerable to neurodegeneration during long-term methamphetamine administration [14, 231]. In contrast, the hippocampus of ketamine-addicted rats has been reported to show increased levels of Nurr1 due to CREB-medicated phosphorylation [232, 233]. These studies suggest that Nurr1 is involved in the initiation and progression of addictive disorders, which may depend on the type of drug and the duration of administration. As several lines of evidence suggest that reward processing is defective in neurodegenerative diseases including AD [234], the correlation between Nurr1 expression and addictive behaviors may suggest the need for further investigation regarding the relationship between Nurr1 function in AD and addictive behaviors.

\subsection{Attention deficit hyperactivity disorder (ADHD)}

VTA, a dopamine nucleus brain region with robust expression of Nurr1 [235, 236], projects dopamine axons to the prefrontal cortex [237], and dopamine system is considered to be an important part of ADHD pathogenesis [238, 239]. In addition, decreased dopamine synaptic markers have been reported in the dopamine reward pathway in ADHD patients [240]. An in vivo study using Nurr1 knockout mice with prenatal immune activation as an attention impairment model reported that genetic and environmental factors synergistically affected attentional 
impairment as well as additively affected locomotor hyperactivity. Remarkably, Nurr1 heterodeficient mice showed increased locomotor activity, and exhibited altered inflammatory cytokine responses against prenatal immune activation [241]. Although there were inconsistent reports regarding the levels of cytokines in $\mathrm{AD}$, cytokines such as IL- 6 and IL-10 are known to play important roles in AD pathogenesis [242]. Given that two NR4A2 polymorphisms were found in patients with ADHD [243], further studies investigating the changes of Nurr1 expression in ADHD may provide a better understanding of $\mathrm{AD}$ pathogenesis.

\subsection{Circadian rhythm disorder}

Disorders of the midbrain dopaminergic neurons, which are the basis of the reward system in the brain, are involved in the disruption of the circadian rhythm [244]. Notably, sleep and circadian rhythm disorder are early biomarkers of AD [245, 246]. The circadian nuclear receptor REV-ERB $\alpha$ encoded by the NR1D1 gene, competes with Nurr1 for the regulation of circadian $\mathrm{TH}$ expression via a target-dependent antagonistic mechanism [247]. In 6-month old 3xTg-AD mice, an animal model of $\mathrm{AD}$, gene expression of NR1D1 is increased in the brainstem after exposure to darkness, compared to control mice [248]. Thus, these data may imply that controlling the balance between expression of ERV-ERB $\alpha$ and Nurr 1 could be a potential target for treating circadian rhythm disorder in AD.

\section{Conclusion}

Recent findings regarding the Nurr1 role in the CNS have demonstrated molecular, cellular, and physiological responses underlying various conditions, and these findings may provide insights for the association between Nurr1 and the underlying mechanisms of AD (Fig. 1). Studies on the effect of Nurr1 support the correlation between Nurr1 expression and various stages of $A D$ pathology and symptoms, including neuronal cell death, inflammation, synaptic loss, impaired adult neurogenesis, psychiatric symptoms, and cognitive deficits.

All mechanisms of development of neurodegenerative diseases, especially of $\mathrm{AD}$, are closely related to the actions of Nurr1. Nurr1 may be capable of regulating $\mathrm{AD}$-related pathogenesis, based on recent studies showing the critical roles of Nurr1 in AD-related pathology (Fig. 1). As a result, subsequent experiments have been performed to prove Nurr1 as a potential target for treatment of $\mathrm{AD}$, and have suggested Nurr1 agonists/mimetics as potential therapeutic agents for $\mathrm{AD}$.

\section{Acknowledgments}

This work was supported by the Basic Science Research Program through the National Research Foundation of Korea (NRF) funded by the Ministry of Science, ICT \& Future Planning (NRF-2018R1D1A3B07041059 to M.M and 2017R1D1A1B03035839 to H.C) and by the Cooperative Research Program for Agriculture Science and Technology Development (Project No. PJ01319901 and PJ01428603), Rural Development Administration, Republic of Korea

\section{Conflict of interest}

The authors have no conflict of interest to declare.

\section{References}

[1] Germain P, Staels B, Dacquet C, Spedding M, Laudet $\mathrm{V}$ (2006). Overview of nomenclature of nuclear receptors. Pharmacol Rev, 58:685-704.

[2] Wang Z, Benoit G, Liu J, Prasad S, Aarnisalo P, Liu X, et al. (2003). Structure and function of Nurrl identifies a class of ligand-independent nuclear receptors. Nature, 423:555-560.

[3] Zetterstrom RH, Williams R, Perlmann T, Olson L (1996). Cellular expression of the immediate early transcription factors Nurrl and NGFI-B suggests a gene regulatory role in several brain regions including the nigrostriatal dopamine system. Brain Res Mol Brain Res, 41:111-120.

[4] Saucedo-Cardenas O, Conneely OM (1996). Comparative distribution of NURR1 and NUR77 nuclear receptors in the mouse central nervous system. J Mol Neurosci, 7:51-63.

[5] Luo Y (2012). The function and mechanisms of Nurrl action in midbrain dopaminergic neurons, from development and maintenance to survival. Int Rev Neurobiol, 102:1-22.

[6] Jankovic J, Chen S, Le WD (2005). The role of Nurrl in the development of dopaminergic neurons and Parkinson's disease. Prog Neurobiol, 77:128-138.

[7] Saucedo-Cardenas O, Quintana-Hau JD, Le WD, Smidt MP, Cox JJ, De Mayo F, et al. (1998). Nurrl is essential for the induction of the dopaminergic phenotype and the survival of ventral mesencephalic late dopaminergic precursor neurons. Proc Natl Acad Sci U S A, 95:4013-4018.

[8] Sacchetti P, Carpentier R, Segard P, Olive-Cren C, Lefebvre P (2006). Multiple signaling pathways regulate the transcriptional activity of the orphan nuclear receptor NURR1. Nucleic Acids Res, 34:5515-5527.

[9] Pereira LA, Munita R, Gonzalez MP, Andres ME (2017). Long 3'UTR of Nurrl mRNAs is targeted by miRNAs in mesencephalic dopamine neurons. PLoS One, 12:e188177.

[10] Amelio AL, Caputi M, Conkright MD (2009). 
Bipartite functions of the CREB co-activators selectively direct alternative splicing or transcriptional activation. EMBO J, 28:2733-2747.

[11] Parra-Damas A, Rubio-Ferrarons L, Shen J, Saura CA (2017). CRTC1 mediates preferential transcription at neuronal activity-regulated CRE/TATA promoters. Sci Rep, 7:18004.

[12] Maxwell MA, Muscat GE (2006). The NR4A subgroup: Immediate early response genes with pleiotropic physiological roles. Nucl Recept Signal, 4.

[13] Chu Y, Le W, Kompoliti K, Jankovic J, Mufson EJ, Kordower JH(2006). Nurr1 in Parkinson's disease and related disorders. J Comp Neurol, 494:495-514.

[14] Werme M, Hermanson E, Carmine A, Buervenich S, Zetterstrom RH, Thoren P, et al. (2003). Decreased ethanol preference and wheel running in Nurr1deficientmice. Eur J Neurosci, 17:2418-2424.

[15] Rojas P, Joodmardi E, Hong Y, Perlmann T, Ogren SO (2007). Adult mice with reduced Nurrl expression: an animal model for schizophrenia. Mol Psychiatry, 12:756-766.

[16] Moon M, Jung ES, Jeon SG, Cha MY, Jang Y, Kim W, et al. (2018). Nurr1 (NR4A2) regulates Alzheimer's disease-related pathogenesis and cognitive function in the 5XFAD mouse model. Aging Cell:e1 2866.

[17] Hammond SL, Popichak KA, Li X, Hunt LG, Richman EH, Damale PU, et al. (2018). The Nurr1 Ligand,1,1-bis(3'-Indolyl)-1-(p-

Chlorophenyl)Methane, Modulates Glial Reactivity and Is Neuroprotective in MPTP-Induced Parkinsonism. J Pharmacol Exp Ther, 365:636-651.

[18] Kim JI, Jeon SG, Kim KA, Kim YJ, Song EJ, Choi J, et al. (2016). The pharmacological stimulation of Nurr1 improves cognitive functions via enhancement of adult hippocampal neurogenesis. Stem Cell Res, 17:534-543.

[19] Kim CH, Han BS, Moon J, Kim DJ, Shin J, Rajan S, et al. (2015). Nuclear receptor Nurrl agonists enhance its dual functions and improve behavioral deficits in an animal model of Parkinson's disease. Proc Natl Acad Sci U S A, 112:8756-8761.

[20] Smith GA, Rocha EM, Rooney T, Barneoud P, McLean JR, Beagan J, et al. (2015). A Nurrl agonist causes neuroprotection in a Parkinson's disease lesion model primed with the toll-like receptor 3 dsRNA inflammatory stimulant poly(I:C). PLoS One, 10:e0121072.

[21] Barker WW, Luis CA, Kashuba A, Luis M, Harwood DG, Loewenstein D, et al. (2002). Relative frequencies of Alzheimer disease, Lewy body, vascular and frontotemporal dementia, and hippocampal sclerosis in the State of Florida Brain Bank. Alzheimer Dis Assoc Disord, 16:203-212.

[22] Holtzman DM, Morris JC, Goate AM (2011). Alzheimer's disease: the challenge of the second century. Sci Trans1 Med, 3:77sr71.

[23] Whitehouse PJ, Price DL, Struble RG, Clark AW, Coyle JT, Delon MR (1982). Alzheimer's disease and senile dementia: loss of neurons in the basal forebrain. Science, 215:1237-1239.
[24]

[26] Durazzo TC, Mattsson N, Weiner MW (2014). Smoking and increased Alzheimer's disease risk: a review of potential mechanisms. Alzheimers Dement, 10:S122-145.

[27] Kumar A, Singh A, Ekavali (2015). A review on Alzheimer's disease pathophysiology and its management: an update. Pharmacol Rep, 67:195-203. [28] Lindsay J, Laurin D, Verreault R, Hebert R, Helliwell B, Hill GB, et al. (2002). Risk factors for Alzheimer's disease: a prospective analysis from the Canadian Study of Health and Aging. Am J Epidemiol, 156:445453.

[29] Swerdlow RH (2007). Pathogenesis of Alzheimer's disease. Clinical Interventions in Aging, 2:347-359.

[30] Forstl H (1998). Alzheimer's disease: the size of the problem, clinical manifestation and heterogeneity. J Neural Transm Suppl, 54:1-8.

[31] Nervi A, Reitz C, Tang M-X, Santana V, Piriz A, Reyes D, et al. (2008). Comparison of Clinical Manifestation in Familial Alzheimer's disease and Dementia with Lewy Bodies. Archives of neurology, 65:1634-1639.

[32] Nestor PJ, Scheltens P, Hodges JR (2004). Advances in the early detection of Alzheimer's disease. Nat Med, 10 Suppl:S34-41.

[33] Cummings JL (2004). Alzheimer's Disease. New England Journal of Medicine, 351:56-67.

[34] Van Cauwenberghe C, Van Broeckhoven C, Sleegers $\mathrm{K}$ (2016). The genetic landscape of Alzheimer disease: clinical implications and perspectives. Genet Med, 18:421-430.

[35] Bird TD (2008). Genetic aspects of Alzheimer disease. Genet Med, 10:231-239.

[36] McGleenon BM, Dynan KB, Passmore AP (1999). Acetylcholinesterase inhibitors in Alzheimer's disease. British Journal of Clinical Pharmacology, 48:471-480.

[37] Birks J (2006). Cholinesterase inhibitors for Alzheimer's disease. Cochrane Database Syst Rev:Cd005593.

[38] Butterfield DA, Pocernich CB (2003). The glutamatergic system and Alzheimer's disease: therapeuticimplications. CNS Drugs, 17:641-652.

[39] Parsons CG, Danysz W, Dekundy A, Pulte I (2013). Memantine and Cholinesterase Inhibitors: Complementary Mechanisms in the Treatment of Alzheimer's Disease. Neurotoxicity Research, 24:358-369.

[40] Imbimbo BP, Ottonello S, Frisardi V, Solfrizzi V, Greco A, Seripa D, et al. (2012). Solanezumab for the treatment of mild-to-moderate Alzheimer's disease. Expert Review of Clinical Immunology, 8:135-149.

[41] Adolfsson O, Pihlgren M, Toni N, Varisco Y, 
Buccarello AL, Antoniello K, et al. (2012). An effector-reduced anti-beta-amyloid (Abeta) antibody with unique abeta binding properties promotes neuroprotection and glial engulfment of Abeta. J Neurosci, 32:9677-9689.

[42] Malpass K(2013). Alzheimer disease: Plaque-specific anti-A[beta] antibody shows promise in model of AD. Nat Rev Neurol, 9:61-61.

[43] Panza F, Frisardi V, Solfrizzi V, Imbimbo BP, Logroscino G, Santamato A, et al. (2012). Immunotherapy for Alzheimer's disease: from antibeta-amyloid to tau-based immunization strategies. Immunotherapy, 4:213-238.

[44] Huang Y, Mucke L (2012). Alzheimer mechanisms and therapeutic strategies. Cell, 148:1204-1222.

[45] Selkoe DJ (1994). Alzheimer's disease: a central role for amyloid. J NeuropatholExp Neurol, 53:438-447.

[46] LaFerla FM, Green KN, Oddo S (2007). Intracellular amyloid-beta in Alzheimer's disease. Nat Rev Neurosci, 8:499-509.

[47] Moon M, Hong HS, Nam DW, Baik SH, Song H, Kook SY, et al. (2012). Intracellular amyloid-beta accumulation in calcium-binding protein-deficient neurons leads to amyloid-beta plaque formation in animal model of Alzheimer's disease. J Alzheimers Dis, 29:615-628.

[48] Hawk JD, Abel T (2011). The role of NR4A transcription factors in memory formation. Brain Res Bull, 85:21-29.

[49] Colon-Cesario WI, Martinez-Montemayor MM, Morales S, Felix J, Cruz J, Adorno M, et al. (2006). Knockdown of Nurrl in the rat hippocampus: implications to spatial discrimination learning and memory. Learn Mem, 13:734-744.

[50] Pena de Ortiz S, Maldonado-Vlaar CS, Carrasquillo Y (2000). Hippocampal expression of the orphan nuclear receptor gene hzf-3/nurr1 during spatial discrimination learning. Neurobiol Learn Mem, 74:161-178.

[51] Vuillermot S, Joodmardi E, Perlmann T, Ove Ogren S, Feldon J, Meyer U (2011). Schizophrenia-relevant behaviors in a genetic mouse model of constitutive Nurr1 deficiency. Genes Brain Behav, 10:589-603.

[52] McQuown SC, Barrett RM, Matheos DP, Post RJ, Rogge GA, Alenghat T, et al. (2011). HDAC3 is a critical negative regulator of long-term memory formation. J Neurosci, 31:764-774.

[53] McNulty SE, Barrett RM, Vogel-Ciernia A, Malvaez M, Hernandez N, Davatolhagh MF, et al. (2012). Differential roles for $\mathrm{Nr} 4 \mathrm{a} 1$ and $\mathrm{Nr} 4 \mathrm{a} 2$ in object location vs. object recognition long-term memory. Learn Mem, 19:588-592.

[54] Hawk JD, Bookout AL, Poplawski SG, Bridi M, Rao AJ, Sulewski ME, et al. (2012). NR4A nuclear receptors support memory enhancement by histone deacetylase inhibitors. J Clin Invest, 122:3593-3602.

[55] Bridi MS, Abel T (2013). The NR4A orphan nuclear receptors mediate transcription-dependent hippocampal synaptic plasticity. Neurobiol Leam Mem, 105:151-158.
[56] Barneda-Zahonero B, Servitja JM, Badiola N, Minano-Molina AJ, Fado R, Saura CA, et al. Nurr1 protein is required for N-methyl-D-aspartic acid (NMDA) receptor-mediated neuronal survival. J Biol Chem, 287:11351-11362.

[57] Volakakis N, Kadkhodaei B, Joodmardi E, Wallis K, Panman L, Silvaggi J, et al. NR4A orphan nuclear receptors as mediators of CREB-dependent neuroprotection. Proc Natl Acad Sci U S A, 107:12317-12322.

[58] Zhang T, Wang P, Ren H, Fan J, Wang G (2009). NGFI-B nuclear orphan receptor Nurr1 interacts with p53 and suppresses its transcriptional activity. Mol Cancer Res, 7:1408-1415.

[59] Le W, Conneely OM, He Y, Jankovic J, Appel SH (1999). Reduced Nurrl expression increases the vulnerability of mesencephalic dopamine neurons to MPTP-induced injury. J Neurochem, $73: 2218-2221$.

[60] Sousa KM, Mira H, Hall AC, Jansson-Sjostrand L, Kusakabe M, Arenas E (2007). Microarray analyses support a role for Nurr1 in resistance to oxidative stress and neuronal differentiation in neural stem cells. Stem Cells, 25:511-519.

[61] Kim KS (2017). Toward neuroprotective treatments of Parkinson's disease. Proc Natl Acad Sci U S A, 114:3795-3797.

[62] Espana J, Valero J, Minano-Molina AJ, Masgrau R, Martin E, Guardia-Laguarta C, et al. (2010). betaAmyloid disrupts activity-dependent gene transcription required for memory through the CREB coactivator CRTC1. J Neurosci, 30:9402-9410.

[63] Parra-Damas A, Valero J, Chen M, Espana J, MartinE, Ferrer I, et al. (2014). Crtc1 activates a transcriptional program deregulated at early Alzheimer's diseaserelated stages. J Neurosci, 34:5776-5787.

[64] Moon M, Jeong I, Kim CH, Kim J, Lee PK, MookJung I, et al. (2015). Correlation between orphan nuclear receptor Nurr1 expression and amyloid deposition in 5XFAD mice, an animal model of Alzheimer's disease. J Neurochem, 132:254-262.

[65] Terzioglu-Usak S, Negis Y, Karabulut DS, Zaim M, Isik S (2017). Cellular Model of Alzheimer's Disease: Abeta 1-42 Peptide Induces Amyloid Deposition and a Decrease in Topo Isomerase Ilbeta and Nurr1 Expression. Curr Alzheimer Res, 14:636-644.

[66] Annese A, Manzari C, Lionetti C, Picardi E, Horner DS, Chiara M, et al. (2018). Whole transcriptome profiling of Late-Onset Alzheimer's Disease patients provides insights into the molecular changes involved in the disease. Sci Rep, 8:4282.

[67] Cotman CW, Su JH (1996). Mechanisms of neuronal death in Alzheimer's disease. Brain Pathol, 6:493-506.

[68] Levy OA, Malagelada C, Greene LA (2009). Cell death pathways in Parkinson's disease: proximal triggers, distal effectors, and final steps. Apoptosis, 14:478-500.

[69] Benn SC, Woolf CJ (2005). How do adult neurons survive? Discov Med, 5:309-318.

[70] Koo KA, Kim SH, Oh TH, Kim YC (2006). Acteoside and its aglycones protect primary cultures of rat 
cortical cells from glutamate-induced excitotoxicity. Life Sci, 79:709-716.

[71] Wang X (2009). The antiapoptotic activity of melatonin in neurodegenerative diseases. CNS Neurosci Ther, 15:345-357.

[72] Pan T, Zhu W, Zhao H, Deng H, Xie W, Jankovic J, et al. (2008). Nurr1 deficiency predisposes to lactacystin-induced dopaminergic neuron injury in vitro and in vivo. Brain Res, 1222:222-229.

[73] Bensinger SJ, Tontonoz P (2009). A Nurrl pathway for neuroprotection. Cell, 137:26-28.

[74] Lin X, Parisiadou L, Sgobio C, Liu G, Yu J, Sun L, et al. (2012). Conditional expression of Parkinson's disease-related mutant alpha-synuclein in the midbrain dopaminergic neurons causes progressive neurodegeneration and degradation of transcription factor nuclear receptor related 1. J Neurosci, 32:92489264.

[75] Lallier SW, Graf AE, Waidyarante GR, Rogers LK (2016). Nurr1 expression is modified by inflammation in microglia. Neuroreport, 27:1120-1127.

[76] Lee MK, Nikodem VM (2004). Differential role of ERK in cAMP-induced Nurr1 expression in N2A and C6 cells. Neuroreport, 15:99-102.

[77] O'Kane M, Markham T, McEvoy AN, Fearon U, Veale DJ, FitzGerald O, et al. (2008). Increased expression of the orphan nuclear receptor NURR 1 in psoriasis and modulation following TNF-alpha inhibition. J Invest Dermatol, 128:300-310.

[78] Zetterström RH, Solomin L, Jansson L, Hoffer BJ, Olson L, Perlmann T (1997). Dopamine Neuron Agenesis in Nurr1-Deficient Mice. Science, 276:248250.

[79] Saijo K, Winner B, Carson CT, Collier JG, Boyer L, Rosenfeld MG, et al. (2009). A Nurrl/CoREST pathway in microglia and astrocytes protects dopaminergic neurons from inflammation-induced death. Cell, 137:47-59.

[80] Garcia-Yague AJ, Rada P, Rojo AI, Lastres-Becker I, Cuadrado A (2013). Nuclear import and export signals control the subcellular localization of Nurrl protein in response to oxidative stress. J Biol Chem, 288:55065517.

[81] Volakakis N, Kadkhodaei B, Joodmardi E, Wallis K, Panman L, Silvaggi J, et al. (2010). NR4A orphan nuclear receptors as mediators of CREB-dependent neuroprotection. Proc Natl Acad Sci U S A, 107:12317-12322.

[82] Lee MA, Lee HS, Lee HS, Cho KG, Jin BK, Sohn S, et al. (2002). Overexpression of midbrain-specific transcription factor Nurr1 modifies susceptibility of mouse neural stem cells to neurotoxins. NeurosciLett, 333:74-78.

[83] Jo AY, Kim MY, Lee HS, Rhee YH, Lee JE, Baek KH, et al. (2009). Generation of dopamine neurons with improved cell survival and phenotype maintenance using a degradation-resistant nurr1 mutant. Stem Cells, 27:2238-2246.

[84] Bruning JM, Wang Y, Oltrabella F, Tian B, Kholodar SA, Liu H, et al. (2019). Covalent Modification and
Regulation of the Nuclear Receptor Nurrl by a Dopamine Metabolite. Cell Chem Biol, 26:674685.e676.

[85] Li Y, Sun H, Chen Z, Xu H, Bu G, Zheng H (2016). Implications of GABAergic Neurotransmission in Alzheimer's Disease. Front Aging Neurosci, 8:31.

[86] Limon A, Reyes-Ruiz JM, Miledi R (2012). Loss of functional $\mathrm{GABA}(\mathrm{A})$ receptors in the Alzheimer diseased brain. Proc Natl Acad Sci U S A, 109:1007110076.

[87] Kabba JA, Xu Y, Christian H, Ruan W, Chenai K, Xiang Y, et al. (2018). Microglia: Housekeeper of the Central Nervous System. Cell Mol Neurobiol, 38:5371.

[88] Heneka MT, Carson MJ, El Khoury J, Landreth GE, Brosseron F, Feinstein DL, et al. (2015). Neuroinflammation in Alzheimer's disease. Lancet Neurol, 14:388-405.

[89] Block ML, Zecca L, Hong JS (2007). Microgliamediated neurotoxicity: uncovering the molecular mechanisms. Nat Rev Neurosci, 8:57-69.

[90] Moon M, Choi JG, Nam DW, Hong HS, Choi YJ, Oh MS, et al. (2011). Ghrelin ameliorates cognitive dysfunction and neurodegeneration in intrahippocampal amyloid-beta1-42 oligomer-injected mice. J Alzheimers Dis, 23:147-159.

[91] Moon M, Choi JG, Kim SY, Oh MS (2014). Bombycis excrementum reduces amyloid-beta oligomer-induced memory impairments, neurodegeneration, and neuroinflammation in mice. J Alzheimers Dis, 41:599613.

[92] Moon M, Kim HG, Choi JG, Oh H, Lee PK, Ha SK, et al. (2014). 6-Shogaol, an active constituent of ginger, attenuates neuroinflammation and cognitive deficits in animal models of dementia. Biochem Biophys Res Commun, 449:8-13.

[93] Rodriguez-Calvo R, Tajes M, Vazquez-Carrera M (2017). The NR4A subfamily of nuclear receptors: potential new therapeutic targets for the treatment of inflammatory diseases. Expert Opin Ther Targets, 21:291-304.

[94] Sekiya T, Kashiwagi I, Inoue N, Morita R, Hori S, Waldmann $\mathrm{H}$, et al. (2011). The nuclear orphan receptor $\mathrm{Nr} 4 \mathrm{a} 2$ induces Foxp3 and regulates differentiation ofCD4+ T cells. Nat Commun, 2:269.

[95] McMorrow JP, Murphy EP (2011). Inflammation: a role for NR4A orphan nuclear receptors? Biochem Soc Trans, 39:688-693.

[96] Fan X, Luo G, Ming M, Pu P, Li L, Yang D, et al. (2009). Nurrl expression and its modulation in microglia. Neuroimmunomodulation, 16:162-170.

[97] Alvarez-Castelao B, Losada F, Ahicart P, Castano JG (2013). The N-terminal region of Nurrl (a.a 1-31) is essential for its efficient degradation by the ubiquitin proteasome pathway. PLoS One, 8:e55999.

[98] Akiyama H, Barger S, Barnum S, Bradt B, Bauer J, Cole GM, et al. (2000). Inflammation and Alzheimer's disease. Neurobiol Aging, 21:383-421.

[99] Kalaria RN (1999). The blood-brain barrier and cerebrovascular pathology in Alzheimer's disease. 
Ann N Y Acad Sci, 893:113-125.

[100] Togo T, Akiyama H, Iseki E, Kondo H, Ikeda K, Kato $\mathrm{M}$, et al. (2002). Occurrence of T cells in the brain of Alzheimer's disease and other neurological diseases. J Neuroimmunol, 124:83-92.

[101] Saresella M, Calabrese E, Marventano I, Piancone F, Gatti A, Alberoni M, et al. (2011). Increased activity of Th-17 and Th-9 lymphocytes and a skewing of the post-thymic differentiation pathway are seen in Alzheimer's disease. Brain Behav Immun, 25:539-547.

[102] Yin Y, Wen S, Li G, Wang D (2009). Hypoxia enhances stimulating effect of amyloid beta peptide (25-35) for interleukin 17 and $\mathrm{T}$ helper lymphocyte subtype 17 upregulation in cultured peripheral blood mononuclear cells. Microbiol Immunol, 53:281-286.

[103] Browne TC, McQuillan K, McManus RM, O'Reilly JA, Mills KH, Lynch MA (2013). IFN-gamma Production by amyloid beta-specific Th1 cells promotes microglial activation and increases plaque burden in a mouse model of Alzheimer's disease. J Immunol, 190:2241-2251.

[104] Zhang J, Ke KF, Liu Z, Qiu YH, Peng YP (2013). Th17 cell-mediated neuroinflammation is involved in neurodegeneration of abeta 1-42-induced Alzheimer's disease model rats. PLoS One, 8:e75786.

[105] Fisher Y, Nemirovsky A, Baron R, Monsonego A (2010). T cells specifically targeted to amyloid plaques enhance plaque clearance in a mouse model of Alzheimer's disease. PLoS One, 5:e10830.

[106] Lambracht-Washington D, Qu BX, Fu M, Anderson LD, Jr., Stuve O, Eagar TN, et al. (2011). DNA immunization against amyloid beta 42 has high potential as safe therapy for Alzheimer's disease as it diminishes antigen-specific Th1 and Th17 cell proliferation. Cell MolNeurobiol, 31:867-874.

[107] Navone ND, Perga S, Martire S, Berchialla P, Malucchi S, Bertolotto A (2014). Monocytes and CD4 $+\mathrm{T}$ cells contribution to the under-expression of NR4A2 and TNFAIP3 genes in patients with multiple sclerosis. J Neuroimmunol, 272:99-102.

[108] Gilli F, Lindberg RL, Valentino P, Marnetto F, Malucchi S, Sala A, et al. (2010). Learning from nature: pregnancy changes the expression of inflammation-related genes in patients with multiple sclerosis. PLoS One, 5:e8962.

[109] Achiron A, Grotto I, Balicer R, Magalashvili D, Feldman A, Gurevich M (2010). Microarray analysis identifies altered regulation of nuclear receptor family members in the pre-disease state of multiple sclerosis. Neurobiol Dis, 38:201-209.

[110] Satoh J, Nakanishi M, Koike F, Onoue H, Aranami T, Yamamoto T, et al. (2006). T cell gene expression profiling identifies distinct subgroups of Japanese multiple sclerosis patients. J Neuroimmunol, 174:108118.

[111] Kawakami N, Nagerl UV, Odoardi F, Bonhoeffer T, Wekerle H, Flugel A (2005). Live imaging of effector cell trafficking and autoantigen recognition within the unfolding autoimmune encephalomyelitis lesion. J Exp Med, 201:1805-1814.
[112] Raveney BJ, Oki S, Yamamura T (2013). Nuclear receptor NR4A2 orchestrates Th17 cell-mediated autoimmune inflammation via IL-21 signalling. PLoS One, 8:e56595.

[113] Shinji O (2014). Towards understanding the role of orphan nuclear receptor NR4A2 in Th 17 cell-mediated central nervous system autoimmunity: An experimental approach using an animal model of multiple sclerosis. Clinical and Experimental Neuroimmunology, 5:137-148.

[114] Montarolo F, Perga S, Martire S, Bertolotto A(2015). Nurrl reduction influences the onset of chronic EAE in mice. Inflamm Res, 64:841-844.

[115] Ralph JA, McEvoy AN, Kane D, Bresnihan B, FitzGerald O, Murphy EP (2005). Modulation of orphan nuclear receptor NURR1 expression by methotrexate in human inflammatory joint disease involves adenosine A2 Areceptor-mediated responses. J Immunol, 175:555-565.

[116] Cheng LE, Chan FK, Cado D, Winoto A (1997). Functional redundancy of the Nur77 and Nor-1 orphan steroid receptors in T-cell apoptosis. EMBO J, 16:1865-1875.

[117] Moran AE, Holzapfel KL, Xing Y, Cunningham NR, Maltzman JS, Punt J, et al. (2011). T cell receptor signal strength in Treg and iNKT cell development demonstrated by a novel fluorescent reporter mouse. J Exp Med, 208:1279-1289.

[118] Sekiya T, Kashiwagi I, Yoshida R, Fukaya T, Morita R, Kimura A, et al. (2013). Nr4a receptors are essential for thymic regulatory $\mathrm{T}$ cell development and immune homeostasis. Nat Immunol, 14:230-237.

[119] Marsh SE, Abud EM, Lakatos A, Karimzadeh A, Yeung ST, Davtyan H, et al. (2016). The adaptive immune system restrains Alzheimer's disease pathogenesis by modulating microglial function. Proc Natl Acad Sci U S A, 113:E1316-1325.

[120] Le Page A, Dupuis G, Frost EH, Larbi A, Pawelec G, Witkowski JM, et al. (2018). Role of the peripheral innate immune system in the development of Alzheimer's disease. Exp Gerontol, 107:59-66.

[121] Vincent I, Jicha G, Rosado M, Dickson DW (1997). Aberrant expression of mitotic cdc2/cyclin B1 kinase in degenerating neurons of Alzheimer's disease brain. J Neurosci, 17:3588-3598.

[122] Frade JM, Ovejero-Benito MC (2015). Neuronal cell cycle: the neuron itself and its circumstances. Cell Cycle, 14:712-720.

[123] Yang Y, Geldmacher DS, Herrup K (2001). DNA replication precedes neuronal cell death in Alzheimer's disease. J Neurosci, 21:2661-2668.

[124] Yang Y, Mufson EJ, Herrup K (2003). Neuronal cell death is preceded by cell cycle events at all stages of Alzheimer's disease. J Neurosci, 23:2557-2563.

[125] Casadesus G, Gutierrez-Cuesta J, Lee HG, Jimenez A, Tajes M, Ortuno-Sahagun D, et al. (2012). Neuronal cell cycle re-entry markers are altered in the senescence accelerated mouse P8 (SAMP8). J Alzheimers Dis, 30:573-583.

[126] Patrick GN, Zukerberg L, Nikolic M, de la Monte S, 
Dikkes P, Tsai LH (1999). Conversion of p35 to p25 deregulates Cdk5 activity and promotes neurodegeneration. Nature, 402:615-622.

[127] Seward ME, Swanson E, Norambuena A, Reimann A, Cochran JN, Li R, et al. (2013). Amyloid-beta signals through tau to drive ectopic neuronal cell cycle reentry in Alzheimer's disease. J Cell Sci, 126:12781286.

[128] Iijima K, Ando K, Takeda S, Satoh Y, Seki T, Itohara S, et al. (2000). Neuron-specific phosphorylation of Alzheimer's beta-amyloid precursor protein by cyclindependent kinase 5. J Neurochem, 75:1085-1091.

[129] Liu F, Su Y, Li B, Zhou Y, Ryder J, Gonzalez-DeWhitt $\mathrm{P}$, et al. (2003). Regulation of amyloid precursor protein (APP) phosphorylation and processing by p35/Cdk5 and p25/Cdk5. FEBS Lett, 547:193-196.

[130] Suzuki T, Oishi M, Marshak DR, Czernik AJ, Naim AC, Greengard P (1994). Cell cycle-dependent regulation of the phosphorylation and metabolism of the Alzheimer amyloid precursor protein. EMBO J, 13:1114-1122.

[131] Lee MS, Kao SC, Lemere CA, Xia W, Tseng HC, Zhou $\mathrm{Y}$, et al. (2003). APP processing is regulated by cytoplasmic phosphorylation. J Cell Biol, 163:83-95.

[132] Bai B (2018). U1 snRNP Alteration and Neuronal Cell Cycle Reentry in Alzheimer Disease. Front Aging Neurosci, 10:75.

[133] Kroemer G, Galluzzi L, Vandenabeele P, Abrams J, Alnemri ES, Baehrecke EH, et al. (2009). Classification of cell death: recommendations of the Nomenclature Committee on Cell Death 2009. Cell Death Differ, 16:3-11.

[134] Castro DS, Hermanson E, Joseph B, Wallen A, Aarnisalo P, Heller A, et al. (2001). Induction of cell cycle arrest and morphological differentiation by Nurr1 and retinoids in dopamine MN9D cells. J Biol Chem, 276:43277-43284.

[135] Bonta PI, Pols TW, van Tiel CM, Vos M, Arkenbout EK, Rohlena J, et al. (2010). Nuclear receptor Nurrl is expressed in and is associated with human restenosis and inhibits vascular lesion formation in mice involving inhibition of smooth muscle cell proliferation and inflammation. Circulation, 121:2023-2032.

[136] Sirin O, Lukov GL, Mao R, Conneely OM, Goodell MA (2010). The orphan nuclear receptor Nurr1 restricts the proliferation of haematopoietic stem cells. Nat Cell Biol, 12:1213-1219.

[137] Maijenburg MW, Gilissen C, Melief SM, Kleijer M, Weijer K, Ten Brinke A, et al. (2012). Nuclear receptors Nur77 and Nurr1 modulate mesenchymal stromal cell migration. Stem Cells Dev, 21:228-238.

[138] Vergano-Vera E, Diaz-Guerra E, Rodriguez-TraverE, Mendez-Gomez HR, Solis O, Pignatelli J, et al. (2015). Nurrl blocks the mitogenic effect ofFGF-2 and EGF, inducing olfactory bulb neural stem cells to adopt dopaminergic and dopaminergic-GABAergic neuronal phenotypes. Dev Neurobiol, 75:823-841.

[139] Zu G, Yao J, Ji A, Ning S, Luo F, Li Z, et al. (2017). Nurr1 promotes intestinal regeneration after ischemia/reperfusion injury by inhibiting the expression of p21 (Wafl/Cip1). J Mol Med (Berl), 95:83-95.

[140] Goncalves JT, Schafer ST, Gage FH (2016). Adult Neurogenesis in the Hippocampus: From Stem Cells to Behavior. Cell, 167:897-914.

[141] Gage FH (2000). Mammalian neural stem cells. Science, 287:1433-1438.

[142] Piatti VC, Ewell LA, Leutgeb JK (2013). Neurogenesis in the dentate gyrus: carrying the message or dictating the tone. Front Neurosci, 7:50.

[143] Deng W, Aimone JB, Gage FH (2010). New neurons and new memories: how does adult hippocampal neurogenesis affect learning and memory? Nat Rev Neurosci, 11:339-350.

[144] Mu Y, Gage FH (2011). Adult hippocampal neurogenesis and its role in Alzheimer's disease. Mol Neurodegener, 6:85.

[145] Lazarov O, Marr RA (2010). Neurogenesis and Alzheimer's disease: At the crossroads. Experimental Neurology, 223:267-281.

[146] Church RM, Miller MC, Freestone D, Chiu C, Osgood DP, Machan JT, et al. (2014). Amyloid-beta accumulation, neurogenesis, behavior, and the age of rats. Behav Neurosci, 128:523-536.

[147] Wang B, Wang Z, Sun L, Yang L, Li H, Cole AL, et al. (2014). The amyloid precursor protein controls adult hippocampal neurogenesis through GABAergic interneurons. J Neurosci, 34:13314-13325.

[148] Zhang W, Thevapriya S, Kim PJ, Yu WP, Je HS, Tan $\mathrm{EK}$, et al. (2014). Amyloid precursor protein regulates neurogenesis by antagonizing miR-574-5p in the developing cerebral cortex. Nat Commun, 5:3330.

[149] Shim JW, Park CH, Bae YC, Bae JY, Chung S, Chang MY, et al. (2007). Generation of functional dopamine neurons from neural precursor cells isolated from the subventricular zone and white matter of the adult rat brain using Nurrl overexpression. Stem Cells, 25:1252-1262.

[150] Le W-d, Conneely OM, Zou L, He Y, SaucedoCardenas O, Jankovic J, et al. (1999). Selective Agenesis of Mesencephalic Dopaminergic Neurons in Nurrl-Deficient Mice. Experimental Neurology, 159:451-458.

[151] Kim J-H, Auerbach JM, Rodríguez-Gómez JA, Velasco I, Gavin D, Lumelsky N, et al. (2002). Dopamine neurons derived from embryonic stem cells function in an animal model of Parkinson\&\#39;s disease. Nature, 418:50.

[152] Bae EJ, Lee HS, Park CH, Lee SH (2009). Orphan nuclear receptor Nurr1 induces neuron differentiation from embryonic cortical precursor cells via an extrinsic paracrine mechanism. FEBS Lett, 583:15051510.

[153] Hara K, Matsukawa N, Yasuhara T, Xu L, Yu G, Maki $\mathrm{M}$, et al. (2007). Transplantation of post-mitotic human neuroteratocarcinoma-overexpressing Nurrl cells provides therapeutic benefits in experimental stroke: in vitro evidence of expedited neuronal differentiation and GDNF secretion. J Neurosci Res, 
85:1240-1251.

[154] Park CH, Kang JS, Yoon EH, Shim JW, Suh-Kim H, Lee SH (2008). Proneural bHLH neurogenin 2 differentially regulates Nurrl-induced dopamine neuron differentiation in rat and mouse neural precursor cells in vitro. FEBS Lett, 582:537-542.

[155] Chen X, Qian Y, Wang X, Tang Z, Xu J, Lin H, et al. (2018). Nurrl promotes neurogenesis of dopaminergic neuron and represses inflammatory factors in the transwell coculture system of neural stem cells and microglia. CNS Neurosci Ther.

[156] Ahn JH, Lee JS, Cho JH, Park JH, Lee TK, Song M, et al. (2018). Age-dependent decrease of Nurrl protein expression in the gerbil hippocampus. Biomed Rep, 8:517-522.

[157] Morley JE, Farr SA (2014). The role of amyloid-beta in the regulation of memory. Biochem Pharmacol, $88: 479-485$.

[158] Chen G, Chen KS, Knox J, Inglis J, Bernard A, Martin SJ, et al. (2000). A learning deficit related to age and beta-amyloid plaques in a mouse model of Alzheimer's disease. Nature, 408:975-979.

[159] Lopez-Toledano MA, Ali Faghihi M, Patel NS, Wahlestedt C (2010). Adult neurogenesis: a potential tool for early diagnosis in Alzheimer's disease? J Alzheimers Dis, 20:395-408.

[160] Lin CH, Huang YJ, Lin CJ, Lane HY, Tsai GE (2014). NMDA neurotransmission dysfunction in mild cognitive impairment and Alzheimer's disease. Cur Pharm Des, 20:5169-5179.

[161] Zhang Y, Li P, Feng J, Wu M (2016). Dysfunction of NMDA receptors in Alzheimer's disease. Neurol Sci, 37:1039-1047.

[162] Josselyn SA, Nguyen PV (2005). CREB, synapses and memory disorders: Past progress and future challenges. Current Drug Targets: CNS and Neurological Disorders, 4:481-497.

[163] Lemberger T, Parkitna JR, Chai M, Schütz G, Engblom D (2008). CREB has a context-dependent role in activity-regulated transcription and maintains neuronal cholesterol homeostasis. FASEB Journal, 22:2872-2879.

[164] Abel T, Nguyen PV, Barad M, Deuel TAS, Kandel ER, Bourtchouladze R (1997). Genetic demonstration of a role for PKA in the late phase of LTP and in hippocampus-based long-term memory. Cell, 88:615626.

[165] Huang Yan Y, Kandel ER (1994). Recruitment of longlasting and protein kinase A-dependent long-term potentiation in the CA1 region of hippocampus requires repeated tetanization. Learning Memory, 1:74-82.

[166] Igaz LM, Vianna MRM, Medina JH, Izquierdo I (2002). Two time periods of hippocampal mRNA synthesis are required for memory consolidation of fear-motivated learning. Journal of Neuroscience, 22:6781-6789.

[167] Nguyen PV, Abel T, Kandel ER (1994). Requirement of a critical period of transcription for induction of a late phase of LTP. Science, 265:1104-1107.
[168] Pittenger C, Huang YY, Paletzki RF, Bourtchouladze $\mathrm{R}$, Scanlin H, Vronskaya S, et al. (2002). Reversible inhibition of CREB/ATF transcription factors in region CA1 of the dorsal hippocampus disrupts hippocampus-dependent spatial memory. Neuron, 34:447-462.

[169] Ryan MM, Mason-Parker SE, Tate WP, Abraham WC, Williams JM (2011). Rapidly induced gene networks following induction of long-term potentiation at perforant path synapses in vivo. Hippocampus, 21:541-553.

[170] Pegoraro S, Broccard FD, Ruaro ME, Bianchini D, Avossa D, Pastore G, et al. (2010). Sequential steps underlying neuronal plasticity induced by a transient exposure to gabazine. Journal of Cellular Physiology, 222:713-728.

[171] Vecsey CG, Hawk JD, Lattal KM, Stein JM, Fabian SA, Attner MA, et al. (2007). Histone deacetylase inhibitors enhancememory and synaptic plasticity via CREB: CBP-dependent transcriptional activation. Journal of Neuroscience, 27:6128-6140.

[172] Clarke SE, Jukes MC, Njagi JK, Khasakhala L, Cundill B, Otido J, et al. (2008). Effect of intermittent preventive treatment of malaria on health and education in schoolchildren: a cluster-randomised, double-blind, placebo-controlled trial. Lancet, 372:127-138.

[173] Biffi A, Greenberg SM (2011). Cerebral amyloid angiopathy: a systematic review. J Clin Neurol, 7:1-9.

[174] McCarron MO, Nicoll JA (2004). Cerebral amyloid angiopathy and thrombolysis-related intracerebral haemorrhage. Lancet Neurol, 3:484-492.

[175] Attems J, Jellinger K, Thal DR, Van Nostrand W (2011). Review: sporadic cerebral amyloid angiopathy. Neuropathol Appl Neurobiol, 37:75-93.

[176] Selkoe DJ (2001). Alzheimer's disease: genes, proteins, and therapy. Physiol Rev, 81:741-766.

[177] Pei L, Castrillo A, Chen M, Hoffmann A, TontonozP (2005). Induction of NR4A orphan nuclear receptor expression in macrophages in response to inflammatory stimuli. J Biol Chem, 280:29256-29262.

[178] Bonta PI, van Tiel CM, Vos M, Pols TW, van Thienen JV, Ferreira V, et al. (2006). Nuclear receptors Nur77, Nurr1, and NOR-1 expressed in atheroscleroticlesion macrophages reduce lipid loading and inflammatory responses. Arterioscler Thromb Vasc Biol, 26:22882294.

[179] Kim B, Backus C, Oh S, Hayes JM, Feldman EL (2009). Increased tau phosphorylation and cleavage in mouse models of type 1 and type 2 diabetes. Endocrinology, 150:5294-5301.

[180] Ott A, Stolk RP, van Harskamp F, Pols HA, Hofman A, Breteler MM (1999). Diabetes mellitus and the risk of dementia: The Rotterdam Study. Neurology, 53:19371942.

[181] Whitmer RA, Gunderson EP, Quesenberry CP, Jr., Zhou J, Yaffe K (2007). Body mass index in midlife and risk of Alzheimer disease and vascular dementia. Curr Alzheimer Res, 4:103-109.

[182] Cai H, Cong WN, Ji S, Rothman S, Maudsley S, 
Martin B (2012). Metabolic dysfunction in Alzheimer's disease and related neurodegenerative disorders. Curr Alzheimer Res, 9:5-17.

[183] Zhao Y, Bruemmer D (2010). NR4A orphan nuclear receptors: transcriptional regulators of gene expression in metabolism and vascular biology. Arterioscler Thromb Vasc Biol, 30:1535-1541.

[184] Xu Y, Huang Q, Zhang W, Wang Y, Zeng Q, He C, et al. (2015). Decreased expression levels of Nurrl are associated with chronic inflammation in patients with type 2 diabetes. Mol Med Rep, 12:5487-5493.

[185] Pearen MA, Muscat GE (2010). Minireview: Nuclear hormone receptor 4A signaling: implications for metabolic disease. MolEndocrinol, 24:1891-1903.

[186] Close AF, Rouillard C, Buteau J (2013). NR4A ophan nuclear receptors in glucose homeostasis: a minireview. Diabetes Metab, 39:478-484.

[187] Sutherland RJ (1982). The dorsal diencephalic conduction system: a review of the anatomy and functions of the habenular complex. Neurosci Biobehav Rev, 6:1-13.

[188] Groenewegen HJ, Ahlenius S, Haber SN, Kowall NW, Nauta WJ (1986). Cytoarchitecture, fiber connections, and some histochemical aspects of the interpeduncular nucleus in the rat. J Comp Neurol, 249:65-102.

[189] Herkenham M, Nauta WJ (1979). Efferent connections of the habenular nuclei in the rat. J Comp Neurol, 187:19-47.

[190] Jhou TC, Geisler S, Marinelli M, Degarmo BA, Zahm DS (2009). The mesopontine rostromedial tegmental nucleus: A structure targeted by the lateral habenula that projects to the ventral tegmental area of Tsai and substantia nigra compacta. J Comp Neurol, 513:566596.

[191] Lecourtier L, Kelly PH(2007). A conductor hidden in the orchestra? Role of the habenular complex in monoamine transmission and cognition. Neurosci Biobehav Rev, 31:658-672.

[192] Hikosaka $\mathrm{O}(2010)$. The habenula: from stress evasion to value-based decision-making. Nat Rev Neurosci, 11:503-513.

[193] Contestabile A, Villani L, Fasolo A, Franzoni MF, Gribaudo L, Oktedalen O, et al. (1987). Topography of cholinergic and substance $\mathrm{P}$ pathways in the habenulo-interpeduncular system of the rat. An immunocytochemical and microchemical approach. Neuroscience, 21:253-270.

[194] Lein ES, Hawrylycz MJ, Ao N, Ayres M, Bensinger A, Bernard A, et al. (2007). Genome-wide atlas of gene expression in the adult mouse brain. Nature, 445:168176.

[195] Quina LA, Wang S, Ng L, Turner EE (2009). Brn3a and Nurrl mediate a gene regulatory pathway for habenula development. J Neurosci, 29:14309-14322.

[196] Caldecott-Hazard S, Mazziotta J, Phelps M (1988). Cerebral correlates of depressed behavior in rats, visualized using 14C-2-deoxyglucose autoradiography. J Neurosci, 8:1951-1961.

[197] Shumake J, Edwards E, Gonzalez-Lima F (2003). Opposite metabolic changes in the habenula and
[198] Morris JS, Smith KA, Cowen PJ, Friston KJ, Dolan RJ (1999). Covariation of activity in habenula and dorsal raphe nuclei following tryptophan depletion. Neuroimage, 10:163-172.

[199] Sartorius A, Kiening KL, Kirsch P, von Gall CC, Haberkorn U, Unterberg AW, et al. (2010). Remission of major depression under deep brain stimulation of the lateral habenula in a therapy-refractory patient. Biol Psychiatry, 67:e9-e11.

[200] Chen CH, Zhou W, Liu S, Deng Y, Cai F, Tone M, et al. (2012). Increased NF-kappaB signalling upregulates BACE1 expression and its therapeutic potential in Alzheimer's disease. Int $\mathrm{J}$ Neuropsychopharmacol, 15:77-90.

[201] Maira M, Martens C, Philips A, Drouin J (1999). Heterodimerization between members of the Nur subfamily of orphan nuclear receptors as a novel mechanism for gene activation. Mol Cell Biol, 19:7549-7557.

[202] Cramer PE, Cirrito JR, Wesson DW, Lee CY, Karlo JC, Zinn AE, et al. (2012). ApoE-directed therapeutics rapidly clear beta-amyloid and reverse deficits in $\mathrm{AD}$ mouse models. Science, 335:1503-1506.

[203] Heneka MT, Reyes-Irisarri E, Hull M, Kummer MP (2011). Impact and Therapeutic Potential of PPARs in Alzheimer's Disease. Curr Neuropharmacol, 9:643650.

[204] Mandrekar-Colucci S, Karlo JC, Landreth GE (2012). Mechanisms underlying the rapid peroxisome proliferator-activated receptor-gamma-mediated amyloid clearance and reversal of cognitive deficits in a murine model of Alzheimer's disease. J Neurosci, 32:10117-10128.

[205] Mandrekar-Colucci S, Landreth GE (2011). Nuclear receptors as therapeutic targets for Alzheimer's disease. Expert Opin Ther Targets, 15:1085-1097.

[206] Dubois C, Hengerer B, Mattes H (2006). Identification of a potent agonist of the orphan nuclear receptor Nurr1. ChemMedChem, 1:955-958.

[207] Hintermann S, Chiesi M, von Krosigk U, Mathe D, Felber R, Hengerer B (2007). Identification of a series of highly potent activators of the Nurrl signaling pathway. Bioorg Med Chem Lett, 17:193-196.

[208] Poppe L, Harvey TS, Mohr C, Zondlo J, Tegley CM, Nuanmanee O, et al. (2007). Discovery ofligands for Nurrl by combined use of NMR screening with different isotopic and spin-labeling strategies. J Biomol Screen, 12:301-311.

[209] Kim CH, Leblanc P, Kim KS (2016). 4-amino-7chloroquinoline derivatives for treating Parkinson's disease: implications for drug discovery. Expert Opin Drug Discov, 11:337-341.

[210] Montarolo F, Raffaele C, Perga S, Martire S, Finardi A, Furlan R, et al. (2014). Effects of isoxazolopyridinone $7 \mathrm{e}$, a potent activator of the Nurrl signaling pathway, on experimental autoimmune encephalomyelitis in mice. PLoS One, 9:e108791.

[211] Lesuisse D, Malanda A, Peyronel JF, Evanno Y, 
Lardenois P, De-Peretti D, et al. (2019). Development of a novel NURR1/NOT agonist from hit to lead and candidate for the potential treatment of Parkinson's disease. Bioorg Med Chem Lett, 29:929-932.

[212] Zhang Z, Li X, Xie WJ, Tuo H, Hintermann S, Jankovic J, et al. (2012). Anti-parkinsonian effects of Nurr1 activator in ubiquitin-proteasome system impairment induced animal model of Parkinson's disease. CNS Neurol Disord Drug Targets, 11:768-773.

[213] Ordentlich P, Yan Y, Zhou S, Heyman RA (2003). Identification of the antineoplastic agent 6mercaptopurine as an activator of the orphan nuclear hormone receptor Nurr1. J Biol Chem, 278:2479124799.

[214] Kadkhodaei B, Ito T, Joodmardi E, Mattsson B, Rouillard C, Carta M, et al. (2009). Nurr1 is required for maintenance of maturing and adult midbrain dopamine neurons. J Neurosci, 29:15923-15932.

[215] Castillo SO, Baffi JS, Palkovits M, Goldstein DS, Kopin IJ, Witta J, et al. (1998). Dopamine biosynthesis is selectively abolished in substantia nigra/ventral tegmental area but not in hypothalamic neurons in mice with targeted disruption of the Nurr1 gene. Mol Cell Neurosci, 11:36-46.

[216] Skerrett R, Malm T, Landreth G (2014). Nuclear receptors in neurodegenerative diseases. Neurobiol Dis, 72 Pt A: 104-116.

[217] Dauer W, Przedborski S (2003). Parkinson's disease: mechanisms and models. Neuron, 39:889-909.

[218] Le WD, Xu P, Jankovic J, Jiang H, Appel SH, Smith $\mathrm{RG}$, et al. (2003). Mutations in NR4A2 associated with familial Parkinson disease. Nat Genet, 33:85-89.

[219] Liu H, Wei L, Tao Q, Deng H, Ming M, Xu P, et al. (2012). Decreased NURR1 and PITX3 gene expression in Chinese patients with Parkinson's disease. Eur J Neurol, 19:870-875.

[220] Montarolo F, Perga S, Martire S, Navone DN, Marchet A, Leotta D, et al. (2016). Altered NR4A Subfamily Gene Expression Level in Peripheral Blood of Parkinson's and Alzheimer's Disease Patients. Neurotox Res, 30:338-344.

[221] Spathis AD, Asvos X, Ziavra D, Karampelas T, Topouzis S, Cournia Z, et al. (2017). Nurr1:RXRalpha heterodimer activation as monotherapy for Parkinson's disease. Proc Natl Acad Sci US A, 114:3999-4004.

[222] Dong J, Li S, Mo JL, Cai HB, Le WD (2016). Nurr1 Based Therapies for Parkinson's Disease. CNS Neurosci Ther, 22:351-359.

[223] Xie X, Peng L, Zhu J, Zhou Y, Li L, Chen Y, et al. (2017). miR-145-5p/Nurr1/TNF-alpha SignalingInduced Microglia Activation Regulates Neuron Injury of Acute Cerebral Ischemic/Reperfusion in Rats. Front Mol Neurosci, 10:383.

[224] Bhaskar K, Maphis N, Xu G, Varvel NH, KokikoCochran ON, Weick JP, et al. (2014). Microglial derived tumor necrosis factor-alpha drives Alzheimer's disease-related neuronal cell cycle events. Neurobiol Dis, 62:273-285.

[225] Xing G, Zhang L, Russell S, Post R (2006). Reduction of dopamine-related transcription factors Nurr1 and
NGFI-B in the prefrontal cortex in schizophrenia and bipolar disorders. Schizophr Res, 84:36-56.

[226] Weinstein JJ, Chohan MO, Slifstein M, Kegeles LS, Moore H, Abi-Dargham A (2017). Pathway-Specific Dopamine Abnormalities in Schizophrenia. Biol Psychiatry, 81:31-42.

[227] Arredondo C, Gonzalez M, Andres ME, Gysling K (2016). Opposite effects of acute and chronic amphetamine on Nurr1 and NF-kappaB p65 in the rat ventral tegmental area. Brain Res, 1652:14-20.

[228] Leo D, di Porzio U, Racagni G, Riva MA, Fumagalli F, Perrone-Capano C (2007). Chronic cocaine administration modulates the expression of transcription factors involved in midbrain dopaminergic neuron function. Exp Neurol, 203:472480.

[229] Horvath MC, Kovacs GG, Kovari V, Majtenyi K, Hurd YL, KellerE (2007). Heroin abuse is characterized by discrete mesolimbic dopamine and opioid abnormalities and exaggerated nuclear receptorrelated 1 transcriptional decline with age. J Neurosci, 27:13371-13375.

[230] Krasnova IN, Ladenheim B, Hodges AB, Volkow ND, Cadet JL (2011). Chronic methamphetamine administration causes differential regulation of transcription factors in the rat midbrain. PLoS One, 6:e19179.

[231] Luo Y, Wang Y, Kuang SY, Chiang YH, Hoffer B (2010). Decreased level of Nurrl in heterozygous young adult mice leads to exacerbated acute and longterm toxicity after repeated methamphetamine exposure. PLoS One, 5:e15193.

[232] Guo Y, Luo C, Tu G, Li C, Liu Y, Liu W, et al. (2018). Rhynchophylline Downregulates Phosphorylated cAMP Response Element Binding Protein, Nuclear Receptor-related-1, and Brain-derived Neurotrophic Factor Expression in the Hippocampus of Ketamineinduced Conditioned Place Preference Rats. Pharmacogn Mag, 14:81-86.

[233] Li C, Tu G, Luo C, Guo Y, Fang M, Zhu C, et al. (2018). Effects of rhynchophylline on the hippocampal miRNA expression profile in ketamineaddicted rats. Prog Neuropsychopharmacol Biol Psychiatry.

[234] Perry DC, Kramer JH (2015). Reward processing in neurodegenerative disease. Neurocase, 21:120-133.

[235] Backman C, Perlmann T, Wallen A, Hoffer BJ, Morales M (1999). A selective group of dopaminergic neurons express Nurr1 in the adult mouse brain. Brain Res, 851:125-132.

[236] Katunar MR, Saez T, Brusco A, Antonelli MC (2009). Immunocytochemical expression of dopamine-related transcription factors Pitx 3 and Nurr1 in prenatally stressed adult rats. J Neurosci Res, 87:1014-1022.

[237] Juarez Olguin H, Calderon Guzman D, Hernandez Garcia E, Barragan Mejia G (2016). The Role of Dopamine and Its Dysfunction as a Consequence of Oxidative Stress. Oxid Med Cell Longev, 2016:9730467.

[238] Lowe N, Kirley A, Hawi Z, Sham P, Wickham H, 
Kratochvil CJ, et al. (2004). Joint analysis of the DRD5 marker concludes association with attentiondeficit/hyperactivity disorder confined to the predominantly inattentive and combined subtypes. Am J Hum Genet, 74:348-356.

[239] Maher BS, Marazita ML, Ferrell RE, Vanyukov MM (2002). Dopamine system genes and attention deficit hyperactivity disorder: a meta-analysis. Psychiatr Genet, 12:207-215.

[240] Volkow ND, Wang GJ, Kollins SH, Wigal TL, Newcorn JH, Telang F, et al. (2009). Evaluating dopamine reward pathway in ADHD: clinical implications. JAMA, 302:1084-1091.

[241] Vuillermot S, Joodmardi E, Perlmann T, Ogren SO, Feldon J, Meyer U(2012). Prenatal immune activation interacts with genetic Nurrl deficiency in the development of attentional impairments. J Neurosci, 32:436-451.

[242] Zheng C, Zhou XW, Wang JZ (2016). The dual roles of cytokines in Alzheimer's disease: update on interleukins, TNF-alpha, TGF-beta and IFN-gamma. Transl Neurodegener, 5:7.

[243] Smith KM, Bauer L, Fischer M, Barkley R, Navia BA
(2005). Identification and characterization of human NR4A2 polymorphisms in attention deficit hyperactivity disorder. Am J Med Genet B Neuropsychiatr Genet, 133B:57-63.

[244] Wulff K, Gatti S, Wettstein JG, Foster RG (2010). Sleep and circadian rhythm disruption in psychiatric and neurodegenerative disease. Nat Rev Neurosci, 11:589-599.

[245] Phan T, Malkani R (2019). Sleep and circadian rhythm disruption and stress intersect in Alzheimer's disease. Neurobiology of Stress, 10:100133.

[246] Musiek ES, Xiong DD, Holtzman DM (2015). Sleep, circadian rhythms, and the pathogenesis of Alzheimer disease. Exp Mol Med, 47:e148.

[247] Chung S, Lee EJ, Yun S, Choe HK, Park SB, Son HJ, et al. (2014). Impact of circadian nuclear receptor REV-ERBalpha on midbrain dopamine production and mood regulation. Cell, 157:858-868.

[248] Bellanti F, Iannelli G, Blonda M, Tamborra R, Villani $\mathrm{R}$, Romano A, et al. (2017). Alterations of Clock Gene RNA Expression in Brain Regions of a Triple Transgenic Model of Alzheimer's Disease. J Alzheimers Dis, 59:615-631. 